\title{
Optimizing preoxygenation in adults
}

\author{
Issam Tanoubi, MD · Pierre Drolet, MD • \\ François Donati, MD, PhD
}

Received: 12 February 2009/Accepted: 13 March 2009/Published online: 28 April 2009

(c) Canadian Anesthesiologists' Society 2009

\begin{abstract}
Purpose Preoxygenation increases oxygen reserves and duration of apnea without desaturation (DAWD), thus it provides valuable additional time to secure the airway. The purpose of this Continuing Professional Development (CPD) module is to examine the various preoxygenation techniques that have been proposed and to assess their effectiveness in healthy adults and in obese, pregnant, and elderly patients.

Principal findings The effectiveness of preoxygenation techniques can be evaluated by measuring DAWD, i.e., the time for oxygen saturation to decrease to $<90 \%$. Clinically, preoxygenation is considered adequate when end-tidal oxygen fraction is $>90 \%$. This is usually achieved with a 3min tidal volume breathing (TVB) technique. As a rule, asking the patient to take four deep breaths in $30 \mathrm{sec}(4 \mathrm{DB}$ $30 \mathrm{sec}$ ) yields poorer results. Eight deep breaths in $60 \mathrm{sec}$ (8 DB $60 \mathrm{sec}$ ) is equivalent to TVB $3 \mathrm{~min}$. The DAWD is decreased in obese patients, pregnant women, and patients with increased metabolism. Obese patients may benefit from the head-up position and positive pressure breathing. A TVB technique is preferable in the elderly. Failure to preoxygenate is often due to leaks, which commonly occur in edentulous or bearded patients. In cases of difficult preoxygenation, directly applying the circuit to the mouth might be a useful alternative. Supplying extra oxygen in the nasopharynx during apnea might increase DAWD.

Conclusion Since ventilation and tracheal intubation difficulties are unpredictable, this CPD module recommends
\end{abstract}

I. Tanoubi, MD · P. Drolet, MD · F. Donati, MD, PhD ( $\square)$ Département d'anesthésiologie, Hôpital Maisonneuve-Rosemont and Université de Montréal, 5415, boul l'Assomption, Montréal, QC H1T 2M4, Canada

e-mail: francois.donati@umontreal.ca that all patients be preoxygenated. The TVB 3 min and the 8 $D B 60$ sec techniques are suitable for most patients; however, the 4 DB 30 sec is inadequate.

\section{Continuing Professional Development objectives}

After reading this review, the reader should be able to:

- understand the physiological principles of preoxygenation;

- describe the slow and fast techniques for preoxygenating patients;

- apply the proper techniques in healthy adults with normal weight;

- modify these techniques in obese patients, pregnant women, and the elderly;

- briefly describe preoxygenation devices other than the face mask.

The purpose of preoxygenation is to increase the oxygen reserves of the body, thus preventing hypoxia during a planned or unexpected period of apnea. The term "denitrogenation", indicating that nitrogen in the lungs is replaced by oxygen, is sometimes used instead of "preoxygenation". However, the latter is generally preferred because the primary goal is to provide oxygen, not to remove nitrogen. With adequate preoxygenation, patients can tolerate a longer period of apnea, and an increased margin of safety is created between induction of anesthesia and the moment the airway is secured. This extra time may prove particularly valuable if mask ventilation is difficult or contraindicated and if laryngoscopy and tracheal intubation are more difficult than expected.

The purpose of this Continuing Professional Development (CPD) module is to summarize the physiological principles 
of preoxygenation; to describe the slow and fast techniques for preoxygenating patients; to review the effectiveness of these techniques in healthy adults with normal weight; to evaluate the modifications to be applied in obese, pregnant, and elderly patients; and to provide a brief overview of preoxygenation devices other than the face mask.

\section{Physiology of preoxygenation}

In adults with ideal body weight, oxygen consumption at rest is approximately $3 \mathrm{~mL} \cdot \mathrm{kg}^{-1} \cdot \mathrm{min}^{-1}$ or 200-250 $\mathrm{mL} \cdot \min ^{-1}$. During apnea, mobilizable oxygen reserves located chiefly in the lungs and blood are rapidly depleted. ${ }^{1,2}$ An individual breathing room air has an oxygen reserve of $1.0-1.5 \mathrm{~L}$, most of which is bound to hemoglobin in red blood cells. Theoretically, patients should be able to tolerate apnea that lasts up to 5 or $6 \mathrm{~min}$; however, oxygen saturation $\left(\mathrm{SpO}_{2}\right)$ would decrease below $90 \%$ after 1-2 min. If oxygen is given before the onset of apnea, most of the additional oxygen is stored in the lungs instead of the blood. This procedure creates an oxygen reserve that can be spent before depleting hemoglobinbound oxygen, thus it markedly increases the safe duration of apnea (Fig. 1).

At end expiration, when lung volume is equal to functional residual capacity (FRC), alveloar fraction of oxygen $\left(\mathrm{F}_{\mathrm{AO}_{2}}\right)$ is approximately $16 \%$ in patients breathing air and $95 \%$ in patients breathing oxygen; $\mathrm{CO}_{2}$ occupies the remaining $5 \%$. Breathing $100 \%$ oxygen only marginally increases the blood oxygen content because hemoglobin is nearly $100 \%$ saturated when breathing room air, and oxygen is poorly soluble in plasma. Thus, virtually all of the extra oxygen provided by preoxygenation is found in the lungs. This additional amount can be calculated as equal to the $\mathrm{F}_{\mathrm{AO}_{2}}$ at the end of preoxygenation (theoretically 95\%) minus the $\mathrm{F}_{\mathrm{AO}_{2}}$ when $\mathrm{SpO}_{2}=90 \%\left(\mathrm{~F}_{\mathrm{AO}_{2}} \approx 10 \%\right)$ multiplied by FRC. If $\mathrm{FRC}=2500 \mathrm{~mL}$, the oxygen reserve is $2500(0.95-0.10)=2125 \mathrm{~mL}$ with preoxygenation, compared to only $2500(0.16-0.10)=150 \mathrm{~mL}$ with room air. Assuming an oxygen consumption of $250 \mathrm{~mL} \cdot \mathrm{min}^{-1}$, the $2125 \mathrm{~mL}$ in the patient's lungs can provide 2125/ $250=8.5 \mathrm{~min}$ of apnea.

Healthy humans can tolerate periods of relative hypoxia lasting hours or days ( $\mathrm{SpO}_{2}=80 \%$ or less), as indicated by altitude experiments. However, avoiding $\mathrm{SpO}_{2}<90 \%$ is recommended at induction of anesthesia because $\mathrm{SpO}_{2}$ usually diminishes rapidly after the initial decrease is observed. Therefore, a useful concept is the "safe duration of apnea", also termed duration of apnea without desaturation (DAWD), which is defined here as the interval between the onset of apnea and the time $\mathrm{SpO}_{2}$ reaches a value $\leq 90 \%$. This duration depends on: (1) the oxygen

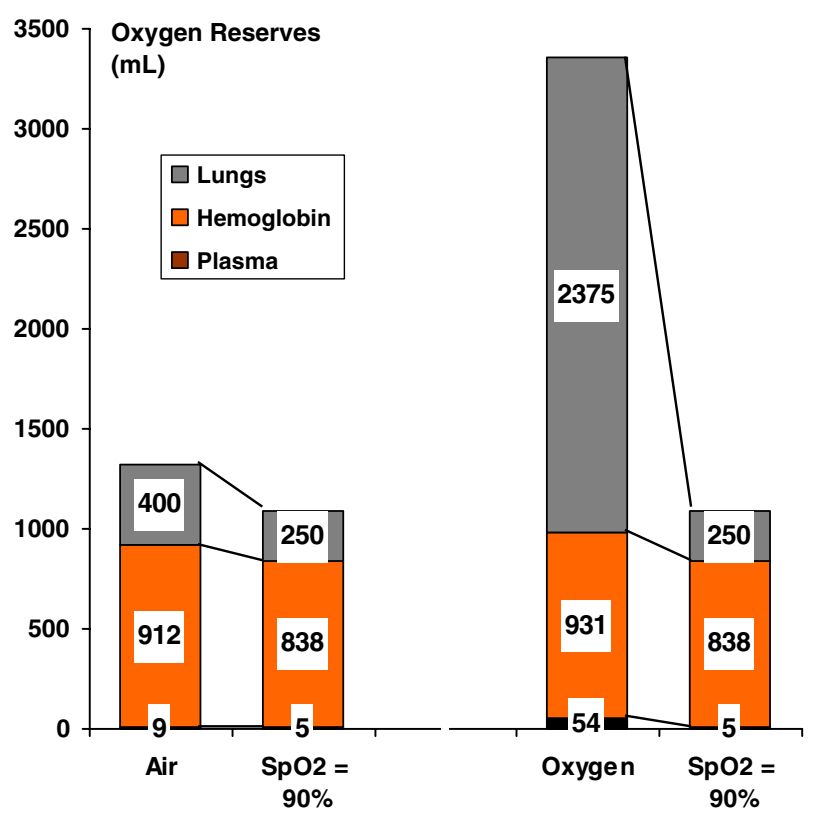

Fig. 1 Oxygen reserves in a normal healthy adult when breathing room air (left), after breathing $100 \%$ oxygen (right), at onset of apnea, and when reaching an oxygen saturation $\left(\mathrm{SpO}_{2}\right)$ of $90 \%$. In this example, the oxygen available for consumption during the apneic period amounts to $228 \mathrm{~mL}$ when breathing air and $2267 \mathrm{~mL}$ when breathing oxygen. Calculations are based on a functional residual capacity of $2500 \mathrm{~mL}$, hemoglobin concentration $140 \mathrm{~g} \cdot \mathrm{L}^{-1}$, $\mathrm{SpO}_{2}=98 \%$ on air, $\mathrm{SpO}_{2}=100 \%$ on oxygen, and blood volume 5 L. In this example, a subject with an oxygen consumption of $250 \mathrm{~mL} \cdot \mathrm{min}^{-1}$ could sustain a period of apnea of $228 / 250=$ 0.9 min after breathing air and $2267 / 250=9$ min after breathing oxygen

reserve at the start of apnea; (2) oxygen consumption; and (3) the amount of oxygen required to maintain $\mathrm{SpO}_{2}=90 \%$ (Table 1). In healthy adults, DAWD is typically $6.9 \mathrm{~min}$ after inhaling $100 \%$ oxygen (slightly less than the calculations above), $5.0 \mathrm{~min}$ after inhaling $80 \%$, 3.5 min after inhaling $60 \%$, and 1 min with room air. ${ }^{3}$

\section{Clinical indications}

Preoxygenation before induction of anesthesia is especially indicated when mask ventilation is contraindicated, for instance, in the case of a presumed full stomach; when difficulties with mask ventilation are anticipated; when tracheal intubation may take longer than usual; with special airway management techniques, such as the insertion of a double lumen tube; in patients who are likely to desaturate quickly, such as those who are obese, pregnant, or febrile; and in patients with pulmonary disease. Since unanticipated difficulties with tracheal intubation are relatively common, preoxygenation is recommended for all patients before induction of general anesthesia. ${ }^{1}$ 
Table 1 Typical examples of duration of apnea without desaturation (DAWD) in different patients

\begin{tabular}{|c|c|c|c|c|c|}
\hline & FRC $(\mathrm{mL})$ & $\begin{array}{l}\mathrm{F}_{\mathrm{EO}_{2}} \text { after } \\
\text { preoxygenation }\end{array}$ & $\begin{array}{l}\mathrm{F}_{\mathrm{EO}_{2}} \text { at } \\
\mathrm{SpO}_{2}=90 \%\end{array}$ & $\begin{array}{l}\mathrm{O}_{2} \text { consumption } \\
\left(\mathrm{mL} \cdot \min ^{-1}\right)\end{array}$ & DAWD (min) \\
\hline No preoxygenation & 2500 & 16 & 10 & 250 & 0.6 \\
\hline Normal preoxygenation & 2500 & 90 & 10 & 250 & 8.0 \\
\hline Poor preoxygenation & 2500 & 60 & 10 & 250 & 5.0 \\
\hline Obese & 1250 & 90 & 10 & 350 & 2.9 \\
\hline Obese head-up & 1500 & 90 & 10 & 350 & 3.4 \\
\hline Pregnant & 1000 & 90 & 10 & 400 & 2.0 \\
\hline Elderly & 2250 & 90 & 10 & 200 & 9.0 \\
\hline
\end{tabular}

Examples only. Actual values may vary. The DAWD is calculated as $\mathrm{FRC}\left(\mathrm{F}_{\mathrm{EO}_{2}}-\mathrm{F}_{\mathrm{EO}_{2}}\right.$ at $\left.\mathrm{SpO}_{2}=90 \%\right) / \mathrm{O}_{2}$ consumption

$\mathrm{FRC}=$ functional residual capacity

DAWD = duration of apnea without desaturation

$\mathrm{F}_{\mathrm{EO}_{2}}=$ expired fraction of oxygen

$\mathrm{SpO}_{2}=$ oxygen saturation

\section{Evaluation of effectiveness}

Duration of apnea

The purpose of preoxygenation is to increase the period of apnea without hypoxia. Thus, the most direct method to evaluate effectiveness is to measure DAWD. Although many studies used this approach to compare different preoxygenation techniques, special care must be taken not to compromise patient safety. An endpoint such as DAWD cannot be used in everyday practice.

Other indicators

Reaching $\mathrm{SpO}_{2}$ of $100 \%$, as measured by pulse oximetry, does not mean that preoxygenation is complete because hemoglobin becomes $100 \%$ saturated at an arterial partial pressure of oxygen $\left(\mathrm{p}_{\mathrm{a}} \mathrm{O}_{2}\right)$ only slightly above that provided by room air. Some studies have measured $\mathrm{p}_{\mathrm{a}} \mathrm{O}_{2}$ using blood gas analysis, but this procedure is impractical. The most useful indicators of the completeness of preoxygenation are end-tidal nitrogen fraction $\left(\mathrm{F}_{\mathrm{EN}_{2}}\right)$ or end-tidal oxygen fraction $\left(\mathrm{F}_{\mathrm{EO}_{2}}\right)$, as both indicators are reflections of the alveolar fraction of nitrogen and oxygen, respectively. With an expired fraction of $\mathrm{CO}_{2}=5 \%$, equivalent to a partial pressure of $40 \mathrm{mmHg}, \mathrm{F}_{\mathrm{EO}_{2}}$ reaches $90 \%$ when $\mathrm{F}_{\mathrm{EN}_{2}}=5 \%$. In the following discussion, only $\mathrm{F}_{\mathrm{EO}_{2}}$ will be mentioned, but it should be remembered that $\mathrm{F}_{\mathrm{EN}_{2}}$ can be used as its surrogate. However, the $\mathrm{F}_{\mathrm{EO}_{2}}$ value alone cannot accurately predict the DAWD because the following three variables are missing: FRC, oxygen consumption, and the amount of oxygen required to maintain $\mathrm{SpO}_{2}=90 \%$. In a given patient, however, these variables cannot be altered in such a manner that DAWD increases with $\mathrm{F}_{\mathrm{EO}_{2}}$ and preoxygenation techniques can be compared using $\mathrm{F}_{\mathrm{EO}_{2}}$ as an endpoint.

\section{How long to preoxygenate?}

Preoxygenation is not effective in the following circumstances: 1) $100 \%$ oxygen is not provided as fresh gas; 2) leaks are present; and/or 3) rebreathing occurs. Thus, a tight fit must be achieved between the mask and the patient's face, and sufficient fresh gas flow of oxygen must be provided to avoid rebreathing $\left(10-12 \mathrm{~L} \cdot \mathrm{min}^{-1}\right)$. Air in the lungs is replaced with oxygen at a rate that depends directly on alveolar minute ventilation and inversely on FRC. It can be calculated that $50 \%$ of the gas is exchanged in a time equal to $\mathrm{FRC} \times \ln (2) /$ alveolar ventilation. For example, with $\mathrm{FRC}=2500 \mathrm{~mL}$ and alveolar ventilation $=3000 \mathrm{~mL}$. $\min ^{-1}$, this half-time equals $2500 \times 0.693 / 3000 \mathrm{~min}$, or 0.58 min. To obtain $95 \%$ gas exchange, that is $\mathrm{F}_{\mathrm{EO}_{2}}>90 \%$, approximately 5 half-times are required, or $2.9 \mathrm{~min}$.

\section{Preoxygenation techniques}

"Slow" techniques

After priming the anesthesia circuit with oxygen, the patient is asked to breathe normally (tidal volume breathing or TVB) until $\mathrm{F}_{\mathrm{EO}_{2}}$ reaches $>90 \%$, which usually takes approximately 3 min (Fig. 2). An $\mathrm{F}_{\mathrm{EO}_{2}}>90 \%$ is a better endpoint than a set time period. When the target $\mathrm{F}_{\mathrm{EO}_{2}}$ cannot be reached, leaks must be suspected. ${ }^{4}$

\section{"Fast" techniques}

Increasing ventilation decreases the time required for the air in the lungs to be replaced with oxygen. Thus, "fast" techniques, which involve asking the patient to take deep or vital capacity breaths, have been proposed. Most studies 


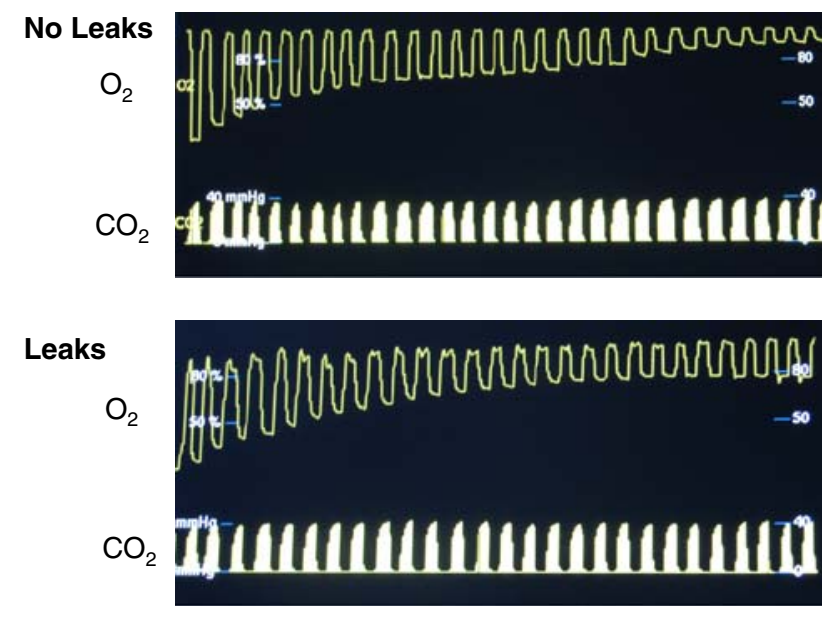

Fig. 2 Examples of preoxygenation with the tidal volume breathing (TVB) technique. Photographs of anesthesia monitor screens where sweep is at $1 \mathrm{~mm} \cdot \mathrm{sec}^{-1}$. In both photographs: top tracing $=$ oxygen fraction; bottom tracing $=\mathrm{CO}_{2}$ fraction. Time from beginning to end of tracings $=3 \mathrm{~min}$. Top photograph: adequate oxygenation with end-tidal oxygen fraction of $93 \%$ after $3 \mathrm{~min}$. Bottom photograph: small leaks are present; notice that $\mathrm{F}_{\mathrm{IO}_{2}}$ does not reach $100 \%$ at beginning of sequence and, even after $3 \mathrm{~min}, \mathrm{~F}_{\mathrm{EO}_{2}}$ does not reach $>77 \%$

in normal patients demonstrated reduced effectiveness with four deep breaths over $30 \mathrm{sec}(4 \mathrm{DB} 30 \mathrm{sec})^{5}$ compared to TVB 3 min (Table 2). ${ }^{4-8}$ Other studies recommended performing eight deep breaths over $60 \mathrm{sec}(8 \mathrm{DB} 60 \mathrm{sec})$, and the best indicators of adequacy of preoxygenation $\left(\mathrm{F}_{\mathrm{EO}_{2}}\right.$ and DAWD) are similar to those afforded by TVB 3 min (Table 2). ${ }^{6-8}$ The 8 DB $60 \mathrm{sec}$ technique might be advantageous in emergency situations, but it requires patient cooperation and a high fresh gas flow. Mild hypocapnia has been observed with the 8 DB $60 \mathrm{sec}$ technique. ${ }^{7}$

\section{Position}

Moving a patient from the upright to the supine position leads to a decrease in FRC. Accordingly, there should be better oxygen reserves after preoxygenation in the upright position, which leads some authors to suggest a head-up position, ${ }^{9}$ particularly in the obese. ${ }^{10,11}$ The drawbacks of the upright position are a risk of hypotension and difficult tracheal intubation.

\section{Application of positive pressure}

Positive end-expiratory pressure (PEEP) can increase FRC, consequently, a technique involving preoxygenation with PEEP and non-invasive positive inspiratory pressure has been suggested. ${ }^{12}$ The initial investigations are encouraging, but it is too early to recommend widespread use of this approach in clinical practice.

\section{Preoxygenation in the obese patient}

Physiology

The DAWD is reduced in obese patients chiefly due to a decrease in FRC. The thorax is compressed by the weight of surrounding tissues, and abdominal content pushes the diaphragm upward in the supine position. Also, oxygen consumption and arteriovenous shunting in the lungs are increased. Jense et al. ${ }^{13}$ found a DAWD of $6.1 \mathrm{~min}$ in lean patients (mean body mass index or BMI $=22 \mathrm{~kg} \cdot \mathrm{m}^{-2}$ ), $4.1 \mathrm{~min}$ in moderately obese patients (mean $\mathrm{BMI}=$ $32 \mathrm{~kg} \cdot \mathrm{m}^{-2}$ ), and $2.7 \mathrm{~min}$ in morbidly obese subjects

Table 2 Comparison of different techniques in non-pregnant adults of normal weight

\begin{tabular}{|c|c|c|c|c|c|}
\hline \multirow[t]{2}{*}{ Study } & \multirow[t]{2}{*}{ Endpoint } & \multicolumn{3}{|c|}{ Preoxygenation technique } & \multirow[t]{2}{*}{ Comments } \\
\hline & & TVB $3 \mathrm{~min}$ & $4 \mathrm{DB} 30 \mathrm{sec}$ & $8 \mathrm{DB} 60 \mathrm{sec}$ & \\
\hline Gambee et al. ${ }^{5}$ & DAWD (min) & $8.9 \pm 1.0$ & $6.8 \pm 1.8$ & a & TVB better than $4 \mathrm{DB}$ \\
\hline Baraka et l. $^{6}$ & DAWD (min) & $3.73 \pm 0.76$ & $2.78 \pm 0.39$ & $5.21 \pm 0.96$ & $\begin{array}{l}\text { Cardiac patients } \\
\text { TVB and } 8 \mathrm{DB} \text { better than } 4 \mathrm{DB}\end{array}$ \\
\hline Nimmagadda et al. ${ }^{7}$ & $\mathrm{~F}_{\mathrm{EO}_{2}}(\%)$ & $88 \pm 5$ & $80 \pm 5$ & $87 \pm 3$ & $\begin{array}{l}\text { Values for a fresh gas flow }=10 \mathrm{~L} \cdot \mathrm{min}^{-1} \\
\text { TVB and } 8 \mathrm{DB} \text { better than } 4 \mathrm{DB}\end{array}$ \\
\hline Pandit et al. ${ }^{8}$ & $\begin{array}{l}\mathrm{F}_{\mathrm{EO}_{2}}(\%) \\
\text { Oxygen uptake (L) }\end{array}$ & $\begin{aligned} 92 & \pm 1 \\
2.23 & \pm 0.95\end{aligned}$ & $\begin{aligned} 83 & \pm 2 \\
1.67 & \pm 0.45\end{aligned}$ & $\begin{aligned} 91 & \pm 4 \\
2.53 & \pm 74\end{aligned}$ & TVB and 8 DB better than 4 DB \\
\hline Gagnon et al. ${ }^{4}$ & $\mathrm{~F}_{\mathrm{EO}_{2}}(\%)$ & $89 \pm 3$ & $76 \pm 7$ & a & TVB better than $4 \mathrm{DB}$ \\
\hline
\end{tabular}

TVB $=$ tidal volume breathing for $3 \mathrm{~min}$

$4 \mathrm{DB} 30 \mathrm{sec}=$ four deep breaths in $30 \mathrm{sec}$

$8 \mathrm{DB} 60 \mathrm{sec}=$ eight deep breaths in $60 \mathrm{sec}$

DAWD $=$ duration of apnea without desaturation

$\mathrm{F}_{\mathrm{EO}_{2}}=$ expired fraction of oxygen

${ }^{\mathrm{a}}$ Not done 
$\left(\right.$ mean $\left.\mathrm{BMI}=43 \mathrm{~kg} \cdot \mathrm{m}^{-2}\right) \quad($ Table 1$)$. A reduced FRC allows for a faster wash-in of oxygen, i.e., the time to reach maximum $\mathrm{F}_{\mathrm{EO}_{2}}$ was less with increasing weight, with a mean of 3.9, 3.7, and 2.9 min in lean, moderately obese, and morbidly obese patients, respectively. ${ }^{13}$ Also, obese individuals have a high closing volume and are prone to atelectasis formation. ${ }^{14}$ In some obese patients, desaturation can occur 1-2 min after apnea begins or the time normally required for a single attempt at laryngoscopy and tracheal intubation. ${ }^{12}$

\section{Preoxygenation techniques}

A decrease in FRC causes $\mathrm{F}_{\mathrm{EO}_{2}}$ to rise faster in obese patients than in lean patients with $\mathrm{TVB}^{13}$ Since vital capacity in obese subjects is also reduced, little may be gained by using rapid preoxygenation techniques. In one study, ${ }^{15} \mathrm{paO}_{2} \mathrm{O}_{2}$ was similar for both the $4 \mathrm{DB} 30 \mathrm{sec}$ and TVB techniques, but more reliable endpoints, such as $\mathrm{F}_{\mathrm{EO}_{2}}$ and DAWD, were not measured. Another study compared $8 \mathrm{DB}$ and TVB and found them equally effective in raising $\mathrm{F}_{\mathrm{EO}_{2}}$ (Table 3). ${ }^{16}$ Thus, if a fast technique is used in obese patients, the $8 \mathrm{DB} 60 \mathrm{sec}$ approach is preferred.

\section{Position}

As FRC is increased, DAWD is expected to be longer when patients are in the head-up position rather than in the supine position. In one study, preoxygenated obese patients could sustain a longer DAWD in the $25^{\circ}$ head-up position than they could in the supine position. ${ }^{11}$ In another study, patients preoxygenated in a sitting position, as close to $90^{\circ}$ as possible, also had a longer DAWD (Table 3 ). ${ }^{10}$ The advantages of the head-up position on oxygenation should be balanced against the possibility of a more difficult tracheal intubation and an increased incidence of hypotension at induction of anesthesia.

Application of positive pressure after induction

Throughout the perioperative period, atelectasis formation is more prevalent in obese than in lean patients. The presence of $100 \%$ oxygen in the lungs favours atelectasis due to oxygen uptake from poorly ventilated alveoli. ${ }^{3,14}$ When air is present, nitrogen, which is not taken up or consumed, provides a "splint" keeping alveoli open. After induction of anesthesia, positive pressure ventilation via a face mask increases DAWD and prevents atelectasis. ${ }^{14}$ Applying PEEP also increases FRC and leads to a longer DAWD. Thus, gently providing positive pressure ventilation following induction, with or without PEEP, may increase the time allowed for tracheal intubation. However, this technique should not be attempted if there is concern regarding aspiration of gastric contents.

Positive pressure ventilation during preoxygenation

Attempts have been made to apply PEEP $\left(4 \mathrm{cmH}_{2} \mathrm{O}\right)$ and pressure support $\left(6 \mathrm{cmH}_{2} \mathrm{O}\right)$ to increase the effectiveness of preoxygenation in obese patients. As expected, time to reach an $\mathrm{F}_{\mathrm{EO}_{2}}>95 \%$ was shorter with PEEP and pressure support, but the DAWD was not prolonged (154 sec $v s$ $161 \mathrm{sec}) .{ }^{12}$ A greater amount of air was found in the

Table 3 Preoxygenation techniques in obese patients

\begin{tabular}{|c|c|c|c|c|c|}
\hline \multirow[t]{2}{*}{ Study } & \multirow[t]{2}{*}{ Endpoint } & \multicolumn{3}{|c|}{ Preoxygenation technique } & \multirow[t]{2}{*}{ Comments } \\
\hline & & TVB $3 \mathrm{~min}$ & 4 or $8 \mathrm{DB}$ & Other technique & \\
\hline Goldberg et al. ${ }^{15}$ & $\mathrm{p}_{\mathrm{a}} \mathrm{O}_{2}(\mathrm{mmHg})$ & 425 & $397(4 \mathrm{DB})$ & $\mathrm{a}$ & $\begin{array}{l}\mathrm{TVB}=4 \mathrm{DB} \text { but } \mathrm{F}_{\mathrm{EO}_{2}} \text { and } \mathrm{DAWD} \\
\text { not measured }\end{array}$ \\
\hline Rapaport et al. ${ }^{16}$ & $\mathrm{~F}_{\mathrm{EO}_{2}}(\%)$ & $88 \pm 5$ & $84 \pm 4(8 \mathrm{DB})$ & $a$ & $8 \mathrm{DB}=\mathrm{TVB}$ \\
\hline Altermatt et al. ${ }^{10}$ & DAWD (min) & & $2.7 \pm 0.6(8 \mathrm{DB})$ & $3.9 \pm 0.6\left(90^{\circ}\right.$ head up $)$ & Head up better than supine \\
\hline Dixon et al. ${ }^{11}$ & DAWD (min) & $2.9 \pm 1.2$ & a & $3.4 \pm 0.9\left(25^{\circ}\right.$ head up $)$ & Head up better than supine \\
\hline Delay et al. $^{12}$ & $\begin{array}{l}\mathrm{F}_{\mathrm{EO}_{2}}(\%) \\
\mathrm{DAWD}(\mathrm{min})\end{array}$ & $\begin{array}{l}94 \pm 2 \\
1.6 \pm 0.6\end{array}$ & a & $\begin{array}{l}97 \pm 1(\mathrm{PPV}) \\
1.7 \pm 0.6(\mathrm{PPV})\end{array}$ & $\begin{array}{l}\text { PPV better than TVB for } \mathrm{F}_{\mathrm{EO}_{2}} \\
\text { but not for DAWD }\end{array}$ \\
\hline
\end{tabular}

TVB $3 \mathrm{~min}=$ tidal volume breathing for $3 \mathrm{~min}$

$4 \mathrm{DB}=$ four deep breaths in $30 \mathrm{sec}$

$8 \mathrm{DB}=$ eight deep breaths in $60 \mathrm{sec}$

$\mathrm{p}_{\mathrm{a}} \mathrm{O}_{2}=$ partial pressure of oxygen in arterial blood

DAWD $=$ duration of apnea without desaturation

$\mathrm{F}_{\mathrm{EO}_{2}}=$ expired fraction of oxygen

$\mathrm{PPV}=$ positive pressure ventilation

${ }^{\text {a }}$ Not done 
stomach of patients who received positive pressure, but the amount was not considered clinically significant (mean $18 \mathrm{~mL}$ vs $4 \mathrm{~mL}$ in the control group). ${ }^{12}$ At present, the evidence available is too limited to recommend the use of this technique on a routine basis.

\section{Preoxygenation in pregnancy}

Physiology

With the increase in abdominal size as pregnancy progresses, the diaphragm is pushed upward and FRC decreases. In addition, both oxygen consumption and minute ventilation increase markedly, while arterial $\mathrm{pCO}_{2}$ decreases. As a result, $\mathrm{F}_{\mathrm{EO}_{2}}$ increases more rapidly during preoxygenation in pregnant women than in non-pregnant women of the same age. For example, nitrogen wash-out to a $2 \%$ end-tidal value took a mean of $80 \mathrm{sec}$ in late pregnancy, compared to $104 \mathrm{sec}$ in early pregnancy and $130 \mathrm{sec}$ in non-pregnant women. ${ }^{17}$ However, DAWD is shorter in pregnant than in non-pregnant women (Table 1). ${ }^{17}$

\section{Preoxygenation technique}

With the TVB technique, the rise in $\mathrm{F}_{\mathrm{EO}_{2}}$ is more rapid in women presenting for cesarean delivery (due to decreased FRC and increased minute ventilation) than it is in nonpregnant females. ${ }^{17}$ However, as in the obese, the effectiveness of the 4 DB $30 \mathrm{sec}$ technique might be limited by a decrease in vital capacity. In one study, DAWD was found to be the same with TVB 3 min and 4 DB $30 \mathrm{sec},{ }^{18}$ but $\mathrm{F}_{\mathrm{EO}_{2}}$ was less after 4 DB $30 \mathrm{sec}$ in two other studies (Table 4). ${ }^{17,19}$ Thus, if a fast technique is used, 8 DB $60 \mathrm{sec}$ is recommended. ${ }^{19}$ However, it must be noted that DAWD may be as short as $1 \mathrm{~min}$ in some patients irrespective of the method of preoxygenation. Contrary to obese patients, the head-up position has not been found to confer any advantage in pregnant women. ${ }^{9}$ This is most likely because parturients and morbidly obese patients have a different fat distribution, and the gravid uterus significantly impairs diaphragmatic excursion, irrespective of the position.

\section{Preoxygenation in the elderly}

\section{Physiology}

In healthy subjects, overall lung volumes do not markedly change with advancing age, but closing volume increases enough to lead to a larger arteriovenous shunt. Since minute ventilation is decreased, it may take longer than the usual 3 min of TVB to achieve adequate $\mathrm{F}_{\mathrm{EO}_{2}}$. However, unless a significant shunt exists due to disease, adequate preoxygenation may allow elderly individuals who exhibit lower oxygen consumption to sustain a slightly longer period of apnea than younger subjects (Table 1).

\section{Preoxygenation techniques}

The TVB method is usually more effective than DB techniques, but the time required for adequate results may be longer than $3 \mathrm{~min}$. The $4 \mathrm{DB} 30 \mathrm{sec}$ technique is not as effective as TVB in the elderly (Table 5), ${ }^{20,21}$ and the 8 DB $60 \mathrm{sec}$ technique has yet to be studied in this age group. In practice, cooperation might be more difficult; leaks may be more frequent because of loss of tone in the jaw and cheek muscles and the absence of teeth, and the shunt may be larger than in younger subjects due to loss of lung tissue from smoking or age.

Table 4 Preoxygenation techniques in pregnant patients

\begin{tabular}{|c|c|c|c|c|c|}
\hline \multirow[t]{2}{*}{ Study } & \multirow[t]{2}{*}{ Endpoint } & \multicolumn{3}{|c|}{ Preoxygenation technique } & \multirow[t]{2}{*}{ Comments } \\
\hline & & TVB 3 min & 4 or $8 \mathrm{DB}$ & Other techniques & \\
\hline Russell et al. ${ }^{17}$ & $\mathrm{~F}_{\mathrm{EO}_{2}}(\%)$ & Not specified & $79 \pm 4(4 \mathrm{DB})$ & a & TVB 3 min better than 4 DB \\
\hline Baraka et al. ${ }^{9}$ & DAWD (min) & $2.9 \pm 0.1$ & a & $2.6 \pm 0.1($ Head up $)$ & Head up does not have advantages \\
\hline Bernard et al. ${ }^{18}$ & DAWD (min) & $2.3 \pm 1.3$ & $2.4 \pm 1.0(4 \mathrm{DB})$ & a & $\mathrm{TVB} 3 \min =4 \mathrm{DB}$ \\
\hline Chiron et al. ${ }^{19}$ & $\mathrm{~F}_{\mathrm{EO}_{2}}(\%)$ & $89 \pm 5$ & $\begin{array}{l}83 \pm 6(4 \mathrm{DB}) \\
90 \pm 6(8 \mathrm{DB})\end{array}$ & a & $\begin{array}{l}\text { TVB } 3 \text { min and } 8 \text { DB better } \\
\text { than TVB } 3 \text { min }\end{array}$ \\
\hline
\end{tabular}

TVB $3 \mathrm{~min}=$ tidal volume breathing for $3 \mathrm{~min}$

$4 \mathrm{DB}=$ four deep breaths in $30 \mathrm{sec}$

$8 \mathrm{DB}=$ eight deep breaths in $60 \mathrm{sec}$

$\mathrm{F}_{\mathrm{EO}_{2}}=$ expired fraction of oxygen

DAWD = duration of apnea without desaturation

${ }^{\text {a }}$ Not done 
Table 5 Preoxygenation techniques in elderly patients

\begin{tabular}{|c|c|c|c|c|}
\hline Study & Endpoint & TVB 3 min & $4 \mathrm{DB} 30 \mathrm{sec}$ & Comments \\
\hline Valentine et $a .^{20}$ & DAWD (min) & $6.8 \pm 1.3$ & $3.9 \pm 1.5$ & TVB better than $4 \mathrm{DB}$ \\
\hline McCarthy et al..$^{21}$ & DAWD (min) & $5.4 \pm 1.4$ & $3.4 \pm 1.4$ & TVB better than $4 \mathrm{DB}$ \\
\hline
\end{tabular}

TVB $3 \mathrm{~min}=$ tidal volume breathing for $3 \mathrm{~min}$

$4 \mathrm{DB} 30 \mathrm{sec}=$ four deep breaths in $30 \mathrm{sec}$

DAWD $=$ duration of apnea without desaturation

\section{Causes of inadequate preoxygenation}

\section{Technical factors}

Although $\mathrm{F}_{\mathrm{EO}_{2}}$ can theoretically reach $95 \%, \mathrm{~F}_{\mathrm{EO}_{2}}>90 \%$ is usually considered satisfactory in practice. Failure to reach such a level may be due to: 1) a low fresh gas flow of oxygen; 2) an inadequate preoxygenation time; and/or 3) leaks. While the first two factors may be easily corrected, leaks are frequent and may be more difficult to diagnose and correct. Leaks have been reported in as many as $11.5 \%$ of patients with teeth and normal facial anatomy. ${ }^{22}$ They may be more frequent in edentulous or bearded subjects or in patients with facial anomalies, burns, or a nasogastric tube. ${ }^{4}$ Leaks should be suspected if the bag in the circuit does not stay inflated, if gas can be felt to escape around the face mask, or if $\mathrm{F}_{\mathrm{EO}_{2}}$ plateaus in the 50-80\% range (Fig. 2). ${ }^{4}$

\section{Human factors}

Preoxygenation might be difficult or impossible if the patient is uncooperative, claustrophobic, or overly anxious or if anesthesia must be induced very rapidly. In these cases, rapid techniques might be useful. They require less time, and a patient might cooperate better if asked to perform a short duration task that requires some attention.

\section{Patient-circuit interface}

The interface between the breathing circuit and the patient is usually a face mask, which may be rejected by some patients and is prone to leaks. Other alternatives have been proposed to improve preoxygenation, avoid leaks, or prolong DAWD.

\section{High oxygen flow rates}

If oxygen is provided at a rate greater than the maximum inspiratory flow rate, leaks are not a concern. Flow rates may reach $30 \mathrm{~L} \cdot \min ^{-1}$ during quiet breathing. Adequate preoxygenation can be provided with oxygen at a flow rate of $48 \mathrm{~L} \cdot \min ^{-1}$ through a loose-fitting mask; ${ }^{23}$ anesthesia machines do not normally provide such high flows. The use of the $\mathrm{O}_{2}$ flush mode is not recommended because of the high pressure delivered.

\section{Circuit to mouth}

In situations where a leak is likely (e.g., beard, nasogastric tube) or where the patient does not accept the face mask, it is possible to ask the patient to apply his/her mouth directly around the circuit connector. When patients perform TVB, it is often necessary to use a nose clip. However, with rapid techniques, nose breathing is infrequent and a nose clip is usually not necessary. ${ }^{24}$

\section{NasOral System ${ }^{\circledR}$}

Designed specifically for preoxygenation, the NasOral ${ }^{\circledR}$ System (Logo Med, GmbH, Windhagen, Germany) is a device that allows inspiration through the nose and expiration through the mouth via unidirectional valves, avoiding rebreathing. The $\mathrm{F}_{\mathrm{EO}_{2}}$ obtained with this system is comparable to that of the face mask. However, the clinician needs to switch to a different breathing system when the patient loses consciousness. Moreover, this device cannot be used in patients who cannot breathe through their nose or mouth. ${ }^{25}$ These drawbacks, plus the additional cost of the $\mathrm{NasOraL}^{\circledR}$ system, have hindered the introduction of this device into clinical practice.

Nasopharyngeal catheter

Oxygen is taken up from the alveoli and consumed during apnea. It is replaced by a much smaller volume of $\mathrm{CO}_{2}$ because of the high buffering capacity of blood for $\mathrm{CO}_{2}$. Thus, if the airway is patent, gas is drawn from the upper airway into the alveoli, even in the absence of respiratory movements. If that gas is chiefly comprised of oxygen, it provides an extra reserve to the body and prolongs the DAWD. For this reason, organ donors avoid hypoxia during an apnea test if oxygen is provided through the tracheal tube. The same principle applies when a catheter connected to an oxygen source at $2-5 \mathrm{~L} \cdot \mathrm{min}^{-1}$ is inserted nasally or orally after induction of anesthesia. In one study, all patients who had a nasopharyngeal catheter with oxygen $\left(5 \mathrm{~L} \cdot \min ^{-1}\right)$ 
had an $\mathrm{SpO}_{2}=100 \%$ after 6 min of apnea, while those without oxygen had a decrease in $\mathrm{SpO}_{2}$ to $95 \%$ in a mean time of 3.65 min. $^{26}$ In another trial, insufflation of $3 \mathrm{~L} \cdot \mathrm{min}^{-1}$ extended the period of apnea from $7 \mathrm{~min}$ to more than 10 min. ${ }^{27}$ This technique has successfully been employed in obese patients, with DAWD increasing from a mean of 2.4 min without such a device to $4 \min$ in 16 of 17 patients when oxygen was provided by a nasopharyngeal cannula at a rate of $5 \mathrm{~L} \cdot \mathrm{min}^{-1}{ }^{28}$ One of the drawbacks of this technique is that it requires an extra manipulation after induction of anesthesia.

\section{Side effects of preoxygenation}

Hemodynamic effects

Oxygen has small but measurable cardiovascular effects. It increases systemic vascular resistance and decreases cardiac output and heart rate. ${ }^{29}$ These changes are minor.

Effect on blood gases

Apart from an increase in $\mathrm{p}_{\mathrm{a}} \mathrm{O}_{2}$, preoxygenation may decrease $\mathrm{pCO}_{2}$ if deep breathing (fast) techniques are employed. ${ }^{4,7} \mathrm{~A}$ decrease in arterial $\mathrm{pCO}_{2}$ may increase the required dose of induction agents, probably due to a concomitant decrease in cerebral blood flow resulting from hypocarbia. ${ }^{30}$ During apnea, $\mathrm{pCO}_{2}$ increases at a rate of $3-$ $6 \mathrm{mmHg} \cdot \mathrm{min}^{-1}$.

\section{Atelectasis}

Atelectatic areas are more often detected after breathing $100 \%$ oxygen than after breathing $60 \%$ or even $80 \%$ oxygen. ${ }^{3}$ Obese patients are prone to developing such a complication. ${ }^{14}$ However, many maneuvers, such as the use of PEEP and recruitment methods, may be utilized during anesthesia and mechanical ventilation to limit the extent of this problem. ${ }^{14}$ Moreover, atelectasis is more prevalent in the postoperative period, and it mostly depends on postoperative hypoventilation and the inspired oxygen concentration at the end of anesthesia. Therefore, it is not justified to avoid preoxygenation for the sole purpose of preventing atelectasis.

\section{Conclusion}

Preoxygenation is an essential first step in airway management because it decreases the risk of hypoxia after induction of anesthesia. The duration of apnea without desaturation not only depends on the preoxygenation method (slow or fast), but it also depends on FRC and oxygen consumption. The TVB $3 \mathrm{~min}$ or the $8 \mathrm{DB}$ $60 \mathrm{sec}$ techniques should be used, and the 4 DB $30 \mathrm{sec}$ technique should be abandoned. Obese and pregnant patients are at special risk for hypoxia and require careful preoxygenation.

\section{Case scenario}

A 65 -year-old patient with weight $110 \mathrm{~kg}$, height $170 \mathrm{~cm}$, and body mass index $38 \mathrm{~kg} \cdot \mathrm{m}^{-2}$ is scheduled for emergency laparotomy for bowel obstruction. The patient has the following vital signs: arterial blood pressure 140/ $85 \mathrm{mmHg}$, heart rate $110 \mathrm{~min}^{-1}$, respiratory rate $24 \mathrm{~min}^{-1}$, temperature $38.8^{\circ} \mathrm{C}$, and oxygen saturation $92 \%$ on air. Computerized tomography (CT scan) of the abdomen shows ascites of undetermined origin. His chest radiograph shows atelectasis at both bases. He has no relevant medical history. A nasogastric tube has been inserted. Airway examination reveals absence of anomalies and an easy tracheal intubation is anticipated. You decide to perform a rapid sequence induction.

\section{Instructions for completing the CPD module}

(1) Read the references indicated in bold.

(2) Visit the Canadian Journal of Anesthesia website (http://www.springer.com/medicine/anesthesiology/ journal/12630), click "CDP online", and select the current module (Optimizing Preoxygenation in Adults).

(3) Answer the multiple choice questions regarding the case.

(4) After you have entered all of your answers, you will have access to an expert's explanation for all of the possible choices.

(5) Participants may claim up to four hours, for a total of eight credits, under Section 3 of the CPD program of the Royal College of Physicians and Surgeons of Canada.

\section{Optimiser la préoxygénation chez l'adulte}

\section{Résumé}

Objectif La préoxygénation est une technique qui augmente les réserves d'oxygène et prolonge la période d'apnée sans désaturation (PASD), offrant ainsi le temps nécessaire à la prise en charge des voies aériennes. 
L'objectif de ce module de Développement professionnel continu (DPC) est d'examiner les différentes techniques de préoxygénation qui ont été proposées et d'évaluer leur efficacité chez l'adulte sain, ainsi que chez le patient obèse, la femme enceinte et le patient âgé.

Constatations principales L'efficacité des techniques de préoxygénation peut être évaluée en mesurant la PASD, soit le temps écoulé avant que la saturation en oxygène diminue à $<90 \%$. Cliniquement, la préoxygénation est considérée adéquate lorsque la fraction d'oxygène télé-expiratoire est $>90 \%$. En général, on y parvient avec une technique de respiration à volume courant $(R V C)$ pendant 3 min. Les résultats sont toutefois moins concluants si l'on demande au patient de prendre quatre respirations profondes $(R P)$ en 30 $\mathrm{sec}(4 \mathrm{RP} 30 \mathrm{sec})$. En revanche, huit respirations profondes en $60 \mathrm{sec}(8 \mathrm{RP} 60 \mathrm{sec})$ donnent des résultats comparables à la RVC 3 min. La PASD est réduite chez le patient obèse, la femme enceinte et les patients présentant un métabolisme accru. Les patients obèses pourraient bénéficier d'une technique en position semi-assise et de l'ajout de pression positive ventilatoire. Une technique de RVC est privilégiée chez le patient âgé. L'échec de la préoxygénation est généralement attribuable à des fuites, phénomène courant chez les patients édentés ou barbus. L'application du circuit directement à la bouche pourrait constituer une bonne alternative dans les situations de préoxygénation difficile. L'administration d'oxygène au niveau du nasopharynx pendant l'apnée pourrait augmenter la PASD.

Conclusion Les difficultés liées à la ventilation et à l'intubation trachéale étant imprévisibles, il est recommandé dans ce module de DPC de préoxygéner tous les patients. Les techniques de RVC 3 min et de 8 RP $60 \mathrm{sec}$, mais non la technique de $4 R P 30 \mathrm{sec}$, conviennent à la plupart des patients.

\section{Objectifs de Développement professionnel continu}

Après avoir complété ce module, le lecteur devrait pouvoir :

- Comprendre les principes physiologiques de la préoxygénation;

- Décrire les techniques de préoxygénation lentes et rapides;

- Appliquer les techniques convenant aux patients adultes sains de poids normal;

- Modifier ces techniques chez les patients obèses, les femmes enceintes et les patients âgés;

- Décrire brièvement les dispositifs de préoxygénation autres que le masque facial.

L'objectif de la préoxygénation est d'augmenter les réserves d'oxygène de l'organisme, afin d'éviter l'hypoxie pendant une période d'apnée programmée ou inattendue.
Le terme «dénitrogénation » est parfois utilisé plutôt que celui de «préoxygénation », indiquant que l'azote présent dans les poumons est remplacé par de l'oxygène. Toutefois, le terme "préoxygénation » est en général privilégié car l'objectif principal est de fournir de l'oxygène et non d'extraire l'azote. Grâce à une préoxygénation adaptée, les patients peuvent tolérer une plus longue période d'apnée, ce qui crée une marge de sécurité accrue entre l'induction de l'anesthésie et la prise en charge des voies aériennes. Ce temps supplémentaire peut être particulièrement salvateur si la ventilation au masque est difficile ou contre-indiquée, ou si la laryngoscopie et l'intubation trachéale s'avèrent plus difficiles que prévues.

L'objectif de ce module de Développement professionnel continu (DPC) est de présenter brièvement les principes physiologiques de la préoxygénation ; de décrire les techniques lentes et rapides qui peuvent être utilisées pour préoxygéner les patients ; de passer en revue l'efficacité de ces techniques chez des patients adultes sains de poids normal ; d'évaluer les modifications à apporter à ces techniques pour les patients obèses, les femmes enceintes et les patients âgés ; et de présenter brièvement les dispositifs de préoxygénation autres que le masque facial.

\section{Physiologie de la préoxygénation}

Chez l'adulte de poids normal, la consommation d'oxygène au repos est d'environ $3 \mathrm{~mL} \cdot \mathrm{kg}^{-1} \cdot \mathrm{min}^{-1}$ ou 200 $250 \mathrm{~mL} \cdot \mathrm{min}^{-1}$. Pendant l'apnée, les réserves d'oxygène mobilisables situées principalement dans les poumons et le sang s'épuisent rapidement. ${ }^{1,2}$ Un individu inspirant de l'air dispose d'une réserve d'oxygène de 1,0-1,5 L, dont la plus grande partie est liée à l'hémoglobine dans les érythrocytes. En théorie, les patients devraient donc pouvoir tolérer une apnée d'une durée de 5 à 6 min ; toutefois, la saturation en oxygène $\left(\mathrm{SpO}_{2}\right)$ baisserait au-dessous de $90 \%$ après 1 à 2 min. Si l'on donne de l'oxygène avant le début de l'apnée, la plus grande partie de l'oxygène supplémentaire sera stockée dans les poumons au lieu du sang. Ceci crée une réserve d'oxygène qui peut être utilisée avant d'épuiser l'oxygène lié à l'hémoglobine, augmentant ainsi la durée sécuritaire de l'apnée (Fig. 1).

En fin d'expiration, lorsque le volume pulmonaire est égal à la capacité résiduelle fonctionnelle (CRF), la fraction alvéolaire d'oxygène $\left(\mathrm{F}_{\mathrm{AO} 2}\right)$ est d'environ $16 \%$ chez les patients inspirant de l'air et de $95 \%$ chez des patients inspirant de l'oxygène, le $\mathrm{CO}_{2}$ occupant les $5 \%$ restants. L'inspiration d'oxygène à $100 \%$ n'augmente que légèrement le contenu d'oxygène dans le sang parce que l'hémoglobine est pratiquement saturée à $100 \%$ lorsqu'on inspire de l'air, et l'oxygène ne se dissout pas bien dans le plasma. Par conséquent, la quasi totalité de l'oxygène 


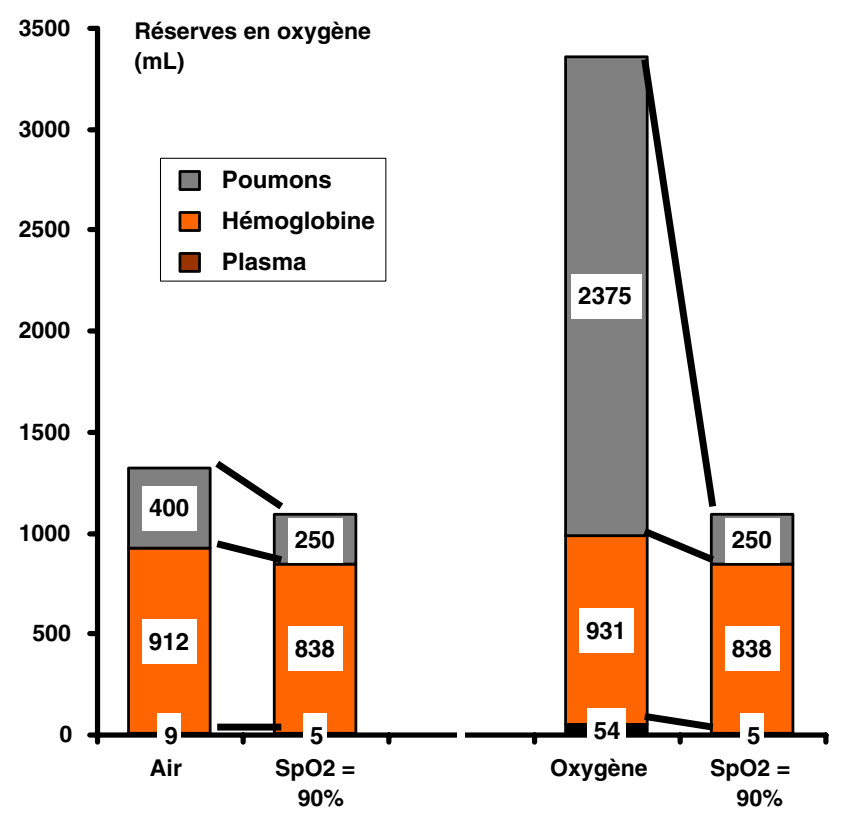

Fig. 1 Réserves d'oxygène chez un patient adulte sain inhalant de l'air (gauche), après avoir inhalé de l'oxygène à $100 \%$, au début de l'apnée, et lorsqu'une saturation d'oxygène $\left(\mathrm{SpO}_{2}\right)$ est atteinte. Dans cet exemple, l'oxygène disponible pour être consommé pendant la période d'apnée s'élève à $228 \mathrm{~mL}$ lorsque de l'air est inhalé et à $2267 \mathrm{~mL}$ lorsque de l'oxygène est inhalé. Les calculs s'appuient sur une capacité résiduelle fonctionnelle de $2500 \mathrm{~mL}$, une concentration d'hémoglobine de $140 \mathrm{~g} \cdot \mathrm{L}^{-1}, \mathrm{SpO}_{2}=98 \%$ à l'air, $\mathrm{SpO}_{2}=100 \%$ avec de l'oxygène, et un volume sanguin de $5 \mathrm{~L}$. Dans cet exemple, un patient avec une consommation d'oxygène de $250 \mathrm{~mL} \cdot \mathrm{min}^{-1}$ pourrait soutenir une période d'apnée de 228/250 =0,9 min après avoir inhalé de l'air et de $2267 / 250=9$ min après avoir inhalé de l'oxygène

supplémentaire fourni par la préoxygénation se trouve dans les poumons. Cette quantité supplémentaire peut être calculée comme étant égale à la $\mathrm{F}_{\mathrm{AO} 2}$ à la fin de la préoxygénation (en théorie $95 \%$ ) moins la $\mathrm{F}_{\mathrm{AO} 2}$ lorsque $\mathrm{SpO}_{2}=90 \%\left(\mathrm{~F}_{\mathrm{AO} 2} \approx 10 \%\right)$, multipliée par la CRF. Si la $\mathrm{CRF}=2500 \mathrm{~mL}$, la réserve d'oxygène est $2500(0,95-0,10)$ $=2125 \mathrm{~mL}$ avec la préoxygénation, comparativement à seulement $2500(0,16-0,10)=150 \mathrm{~mL}$ avec de l'air. Sil'on considère une consommation d'oxygène de $250 \mathrm{~mL} \cdot \mathrm{min}^{-1}$, les $2125 \mathrm{~mL}$ additionnels dans les poumons du patient peuvent fournir $2125 / 250=8,5$ min d'apnée.

Les individus en santé peuvent tolérer des périodes d'hypoxie relative durant des heures, voire des jours $\left(\mathrm{SpO}_{2}=80 \%\right.$ ou moins), comme le démontrent les expériences menées en altitude. Toutefois, il est recommandé d'éviter une $\mathrm{SpO}_{2}<90 \%$ à l'induction de l'anesthésie parce qu'en général la $\mathrm{SpO}_{2}$ diminue rapidement une fois que la réduction initiale est observée. Pour cette raison, un concept utile est la «durée sécuritaire de l'apnée », également nommée période d'apnée sans désaturation (PASD), que l'on définira ici comme l'intervalle entre le début de l'apnée et le moment où la $\mathrm{SpO}_{2}$ atteint une valeur $\leq 90 \%$. Cet intervalle dépend de : 1) la réserve d'oxygène au début de l'apnée ; 2) la consommation d'oxygène ; et 3) la quantité requise d'oxygène pour maintenir une $\mathrm{SpO}_{2}=90 \%$ (Tableau 1). Chez l'adulte sain, la PASD est en général de 6,9 min après administration d'oxygène à $100 \%$ (légèrement moins que prévu par les calculs ci-dessus), de 5,0 min après avoir inhalé de l'oxygène à $80 \%$, de 3,5 min après avoir inhalé de l'oxygène à $60 \%$, et d' 1 min avec de l'air. ${ }^{3}$

\section{Indications cliniques}

La préoxygénation avant l'induction de l'anesthésie est particulièrement indiquée si la ventilation au masque est contre-indiquée, par exemple : lorsqu'on soupçonne un

Tableau 1 Exemples typiques de périodes d'apnée sans désaturation (PASD) chez différents patients

\begin{tabular}{|c|c|c|c|c|c|}
\hline & $\mathrm{CRF}(\mathrm{mL})$ & $\begin{array}{l}\mathrm{F}_{\mathrm{EO} 2} \text { après } \\
\text { préoxygénation }\end{array}$ & $\begin{array}{l}\mathrm{F}_{\mathrm{EO} 2} \mathrm{a} \\
\mathrm{SpO}_{2}=90 \%\end{array}$ & $\begin{array}{l}\text { Consommation } \\
\mathrm{O}_{2}\left(\mathrm{~mL} \cdot \mathrm{min}^{-1}\right)\end{array}$ & PASD (min) \\
\hline Pas de préoxygénation & 2500 & 16 & 10 & 250 & 0,6 \\
\hline Préoxygénation normale & 2500 & 90 & 10 & 250 & 8,0 \\
\hline Mauvaise préoxygénation & 2500 & 60 & 10 & 250 & 5,0 \\
\hline Obèse & 1250 & 90 & 10 & 350 & 2,9 \\
\hline Obèse position semi-assise & 1500 & 90 & 10 & 350 & 3,4 \\
\hline Femme enceinte & 1000 & 90 & 10 & 400 & 2,0 \\
\hline Patient âgé & 2250 & 90 & 10 & 200 & 9,0 \\
\hline
\end{tabular}

Il s'agit d'exemples seulement. Les valeurs réelles peuvent varier. La PASD est calculée comme la $\mathrm{CRF}\left(\mathrm{F}_{\mathrm{EO} 2}-\mathrm{F}_{\mathrm{EO} 2}\right.$ à $\left.\mathrm{SpO} 2=90 \%\right) /$ consommation d' $\mathrm{O}_{2}$

$\mathrm{CRF}=$ capacité résiduelle fonctionnelle;

PASD = période d'apnée sans désaturation;

$\mathrm{F}_{\mathrm{EO} 2}=$ fraction d'oxygène expiré;

$\mathrm{SpO}_{2}=$ saturation en oxygène 
estomac plein ; lorsque des difficultés avec la ventilation au masque sont anticipées ; lorsque l'intubation trachéale peut se prolonger de façon inattendue ; lorsqu'on utilise des techniques spéciales de prise en charge des voies aériennes, comme par exemple l'insertion d'une sonde double lumière ; chez les patients qui risquent de désaturer rapidement, notamment les patients obèses, les femmes enceintes, ou les patients fébriles; et chez les patients souffrant de maladies pulmonaires. Puisque des difficultés imprévues surviennent relativement fréquemment, la préoxygénation est recommandée chez tous les patients lors de l'induction d'une anesthésie générale. ${ }^{1}$

\section{Évaluation de l'efficacité}

\section{Durée de l'apnée}

L'objectif de la préoxygénation est de prolonger la période d'apnée sans hypoxie. Pour cette raison, la mesure de la PASD est la méthode la plus directe pour évaluer son efficacité. Bien que plusieurs études aient eu recours à cette approche pour comparer différentes techniques de préoxygénation, il faut éviter de compromettre la sécurité du patient. Un critère d'évaluation tel que la PASD ne peut donc pas être utilisé dans la pratique quotidienne.

\section{Autres indicateurs}

Une $\mathrm{SpO}_{2}$ de $100 \%$, telle que mesurée par l'oxymétrie de pouls, ne signifie pas que la préoxygénation est complète. En effet, l'hémoglobine devient saturée à $100 \%$ à une pression artérielle partielle d'oxygène $\left(\mathrm{p}_{\mathrm{a}} \mathrm{O}_{2}\right)$ à peine plus élevée que celle fournie par l'air. Certaines études ont mesuré la $\mathrm{p}_{\mathrm{a}} \mathrm{O}_{2}$ en réalisant une gazométrie sanguine, mais cette procédure n'est pas pratique. Les indicateurs les plus utiles d'une préoxygénation complète sont la fraction d'azote télé-expiratoire $\left(\mathrm{F}_{\mathrm{EN} 2}\right)$ ou la fraction d'oxygène télé-expiratoire $\left(\mathrm{F}_{\mathrm{EO} 2}\right)$, ces deux indicateurs reflétant respectivement la fraction alvéolaire d'azote et d'oxygène. Avec une fraction expirée de $\mathrm{CO}_{2}=5 \%$, ce qui équivaut à une pression partielle de $40 \mathrm{mmHg}$, la $\mathrm{F}_{\mathrm{EO} 2}$ atteint $90 \%$ lorsque la $\mathrm{F}_{\mathrm{EN} 2}$ atteint $5 \%$. Dans la discussion qui suit, seule la $\mathrm{F}_{\mathrm{EO} 2}$ sera mentionnée, mais il faut garder à l'esprit que la $\mathrm{F}_{\mathrm{EN} 2}$ peut être utilisée comme substitut. Néanmoins la valeur de la $\mathrm{F}_{\mathrm{EO} 2}$ seule ne peut pas prédire précisément la PASD car il manque les trois variables suivantes : la $\mathrm{CRF}$, la consommation d'oxygène, et la quantité d'oxygène nécessaire pour maintenir une $\mathrm{SpO}_{2}=90 \%$. Chez un patient donné, ces variables ne peuvent toutefois pas être modifiées, de sorte que la PASD augmente avec la $\mathrm{F}_{\mathrm{EO} 2}$ et que les techniques de préoxygénation peuvent être comparées en utilisant la $\mathrm{F}_{\mathrm{EO} 2}$ comme critère d'évaluation.

\section{Combien de temps faut-il préoxygéner un patient ?}

La préoxygénation n'est pas efficace dans les situations suivantes : 1) l'oxygène à $100 \%$ n'est pas administré comme un gaz frais ; 2) il y a des fuites ; et/ou 3) il y a réinspiration. Dès lors, il est important de vérifier que le masque est bien ajusté au visage du patient, et qu'il y a un débit de gaz frais suffisant afin d'éviter la réinspiration $\left(10-12 \mathrm{~L} \cdot \min ^{-1}\right)$. L'air dans les poumons est remplacé par l'oxygène à une vitesse qui dépend directement de la ventilation alvéolaire minute et inversement de la CRF. On peut calculer que $50 \%$ du gaz est échangé pendant un temps égal

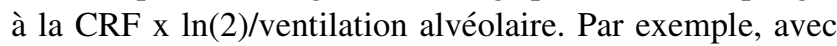
une $\mathrm{CRF}=2500 \mathrm{~mL}$ et une ventilation alvéolaire $=3000$ $\mathrm{mL} \cdot \mathrm{min}^{-1}$, remplacer $50 \%$ des gaz prendra $2500 \times 0,693 /$ $3000 \mathrm{~min}$, ou 0,58 min. Pour remplacer $95 \%$ du contenu alvéolaire, ce qui permet d'obtenir une $\mathrm{F}_{\mathrm{EO} 2}>90 \%$, il faut environ 5 fois plus de temps, soit 2,9 min.

\section{Les techniques de préoxygénation}

Les techniques « lentes»

Après avoir rempli le circuit anesthésique avec de l'oxygène, on demande au patient de respirer normalement (respiration à volume courant ou RVC) jusqu'à ce que la $\mathrm{F}_{\mathrm{EO} 2}$ atteigne $>90 \%$, ce qui prend environ 3 min (Fig. 2). Viser une $\mathrm{F}_{\mathrm{EO} 2}>90 \%$ est une meilleure stratégie que de se fier à une période de temps prédéterminée. Lorsqu'il est impossible d'atteindre la $\mathrm{F}_{\mathrm{EO} 2}$ cible, il faut alors envisager la présence de fuites. ${ }^{4}$

Les techniques « rapides »

L'augmentation de la ventilation réduit le temps nécessaire à l'échange de l'air dans les poumons pour de l'oxygène. Ainsi des techniques "rapides » ont été proposées, lesquelles impliquent de demander au patient d'inhaler profondément, en faisant une manœuvre de capacité vitale. La plupart des études portant sur des patients normaux ont démontré l'efficacité réduite d'une technique de 4 respirations profondes en $30 \mathrm{sec}(4 \mathrm{RP} 30 \mathrm{sec})^{5}$ comparativement à une RVC 3 min (Tableau 2). ${ }^{4-8}$ D'autres études recommandent la prise de huit respirations profondes en $60 \mathrm{sec}$ (8 RP $60 \mathrm{sec}$ ) : les indicateurs les plus fins d'une bonne préoxygénation ( $\mathrm{F}_{\mathrm{EO} 2}$ et $\left.\mathrm{PASD}\right)$ atteignent ainsi des valeurs semblables à celles obtenues avec une RVC 3 min (Tableau 2) ${ }^{6-8} \mathrm{La}$ technique de $8 \mathrm{RP} 60 \mathrm{sec}$ pourrait s'avérer avantageuse dans les situations d'urgence, mais elle nécessite la coopération du patient et un débit de gaz frais élevé. Une légère hypocapnie a été observée avec la technique de $8 \mathrm{RP}$ 60 sec. $^{7}$ 

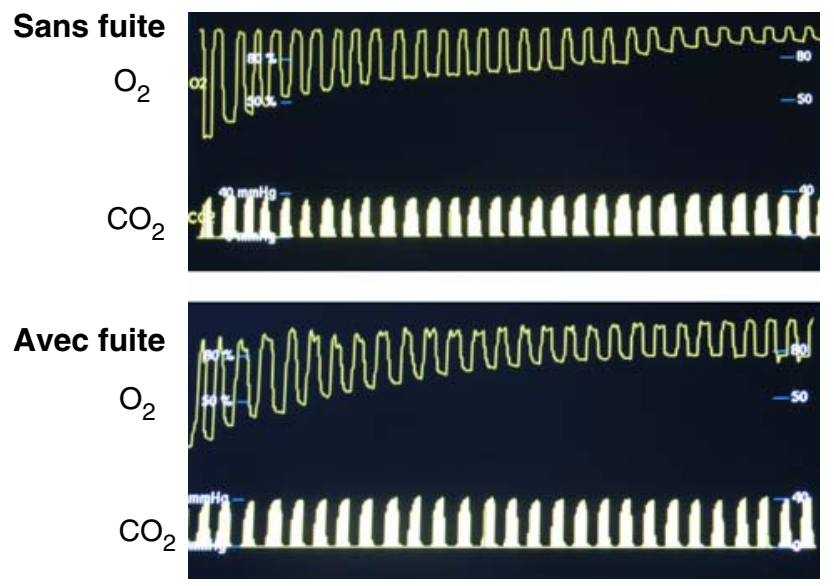

Fig. 2 Exemples de préoxygénation avec la technique de respiration à volume courant (RVC). Photographies de l'écran du moniteur d'anesthésie avec un balayage à $1 \mathrm{~mm} \cdot \mathrm{sec}^{-1}$. Sur les deux photographies : tracé supérieur $=$ fraction d'oxygène ; tracé inférieur $=$ fraction de $\mathrm{CO}_{2}$. Temps entre le début et la fin des tracés $=3 \mathrm{~min}$. Photographie du haut: oxygénation adéquate avec une fraction d'oxygène télé-expiratoire de $93 \%$ après $3 \mathrm{~min}$. Photographie du bas : présence de petites fuites ; remarquez que la $\mathrm{F}_{\mathrm{IO} 2}$ n'atteint pas $100 \%$ au début de la séquence et, même après 3 min, la $\mathrm{F}_{\mathrm{EO} 2}$ n'atteint pas $>77 \%$

\section{Position}

Lorsqu'un patient passe de la position assise à la position de décubitus dorsal, la CRF diminue. Ainsi, il devrait y avoir de meilleures réserves d'oxygène après une préoxygénation réalisée en position assise. Ceci a incité certains auteurs à préconiser une position semi-assise, ${ }^{9}$ plus particulièrement pour les patients obèses. ${ }^{10,11}$ La position assise risque cependant d'accroître l'hypotension et de rendre l'intubation trachéale difficile.
Application de pression positive

La pression positive télé-expiratoire (PEEP) peut augmenter la $\mathrm{CRF}$, par conséquent, une technique de préoxygénation combinant la PEEP à une pression d'aide inspiratoire a été proposée. ${ }^{12}$ Les premiers résultats sont encourageants, mais il est encore trop tôt pour recommander une utilisation généralisée de cette approche en pratique clinique.

\section{La préoxygénation chez le patient obèse}

Physiologie

La PASD est réduite chez le patient obèse principalement en raison d'une réduction de la CRF. Le thorax est comprimé par le poids des tissus mous et, en décubitus dorsal, le contenu abdominal pousse le diaphragme vers le haut. De plus, la consommation d'oxygène et le shunt intrapulmonaire sont augmentés. Jense et coll. ${ }^{13}$ ont mesuré une PASD de 6,1 min chez des patients de poids normal (indice de masse corporelle ou IMC moyen $=22 \mathrm{~kg} \cdot \mathrm{m}^{-2}$ ), de 4,1 min chez des patients modérément obèses (IMC moyen $=32 \mathrm{~kg} \cdot \mathrm{m}^{-2}$ ), et de $2,7 \mathrm{~min}$ chez les obèses morbides $\left(\mathrm{IMC}\right.$ moyen $\left.=43 \mathrm{~kg} \cdot \mathrm{m}^{-2}\right)($ Tableau 1$)$. Une CRF réduite permet un échange plus rapide de l'oxygène, c'est-à-dire que plus la surcharge pondérale est importante, plus le temps requis pour atteindre la $\mathrm{F}_{\mathrm{EO} 2}$ maximale se réduit, avec une moyenne de 3,9, 3,7 et 2,9 min respectivement chez les patients de poids normal, modérément obèses et obèses morbides. ${ }^{13}$ De plus, les personnes obèses présentent un volume de fermeture élevé et sont vulnérables à la formation d'atélectasies. ${ }^{14}$ Chez certains patients obèses, la

Tableau 2 Comparaison de différentes techniques chez les adultes sains avec un poids normal (hormis les femmes enceintes)

\begin{tabular}{|c|c|c|c|c|c|}
\hline \multirow[t]{2}{*}{ Étude } & \multirow[t]{2}{*}{ Critère d'évaluation } & \multicolumn{3}{|c|}{ Technique de préoxygénation } & \multirow[t]{2}{*}{ Commentaires } \\
\hline & & RVC 3 min & $4 \mathrm{RP} 30 \mathrm{sec}$ & $8 \mathrm{RP} 60 \mathrm{sec}$ & \\
\hline Gambee et coll. ${ }^{5}$ & PASD (min) & $8,9 \pm 1,0$ & $6,8 \pm 1,8$ & $*$ & RVC mieux que $4 \mathrm{RP}$ \\
\hline Baraka et coll. ${ }^{6}$ & PASD (min) & $3,73 \pm 0,76$ & $2,78 \pm 0,39$ & $5,21 \pm 0,96$ & Chirurgie cardiaque RVC et $8 \mathrm{RP}$ mieux que $4 \mathrm{RP}$ \\
\hline Nimmagadda et coll. ${ }^{7}$ & $\mathrm{~F}_{\mathrm{EO} 2}(\%)$ & $88 \pm 5$ & $80 \pm 5$ & $87 \pm 3$ & $\begin{array}{l}\text { Valeurs pour un débit de gaz frais }=10 \mathrm{~L} \cdot \mathrm{min}^{-1} \\
\mathrm{RVC} \text { et } 8 \mathrm{RP} \text { mieux que } 4 \mathrm{RP}\end{array}$ \\
\hline Pandit et coll. ${ }^{8}$ & $\begin{array}{l}\mathrm{F}_{\mathrm{EO} 2}(\%) \\
\text { Oxygène capté }(\mathrm{L})\end{array}$ & $\begin{aligned} 92 & \pm 1 \\
2,23 & \pm 0,95\end{aligned}$ & $\begin{aligned} 83 & \pm 2 \\
1,67 & \pm 0,45\end{aligned}$ & $\begin{aligned} 91 & \pm 4 \\
2,53 & \pm 74\end{aligned}$ & $\mathrm{RVC}$ et $8 \mathrm{RP}$ mieux que $4 \mathrm{RP}$ \\
\hline Gagnon et coll. ${ }^{4}$ & $\mathrm{~F}_{\mathrm{EO} 2}(\%)$ & $89 \pm 3$ & $76 \pm 7$ & $*$ & RVC mieux que $4 \mathrm{RP}$ \\
\hline
\end{tabular}

$\mathrm{RVC}=$ respiration à volume courant pendant 3 min;

$4 \mathrm{RP} 30 \mathrm{sec}=$ quatre respirations profondes en $30 \mathrm{sec}$;

$8 \mathrm{RP} 60 \mathrm{sec}=$ huit respirations profondes en $60 \mathrm{sec}$;

PASD = période d'apnée sans désaturation;

$\mathrm{F}_{\mathrm{EO} 2}=$ fraction d'oxygène expiré;

$*$ non réalisé 
désaturation peut survenir 1-2 min après le début de l'apnée, soit le temps généralement requis pour une seule tentative de laryngoscopie et d'intubation trachéale. ${ }^{12}$

Techniques de préoxygénation

Une diminution de la CRF provoque une augmentation plus rapide de la $\mathrm{F}_{\mathrm{EO} 2}$ chez le patient obèse que chez le patient mince avec la RVC. ${ }^{13}$ Étant donné que la capacité vitale est également réduite chez le patient obèse, les techniques de préoxygénation rapide n'apportent pas d'avantages réels. Dans une étude, ${ }^{15}$ la $\mathrm{p}_{\mathrm{a}} \mathrm{O}_{2}$ était comparable entre les techniques de 4 RP $30 \mathrm{sec}$ et de RVC, mais des critères d'évaluation plus fiables comme la $\mathrm{F}_{\mathrm{EO} 2}$ et la PASD n'ont pas été mesurés. Une autre étude a montré que les techniques de 8 RP et de RVC présentaient une efficacité comparable pour élever la $\mathrm{F}_{\mathrm{EO} 2}$ (Tableau 3). ${ }^{16}$ Par conséquent, si l'on choisit une technique rapide chez le patient obèse, l'approche de 8 RP 60 sec devrait être privilégiée.

\section{Position}

Étant donné que la CRF est augmentée, la PASD devrait être prolongée lorsque les patients sont en position semiassise plutôt qu'en décubitus dorsal. Dans une étude, les patients obèses préoxygénés ont pu soutenir une PASD plus longue dans une position semi-assise à $25^{\circ}$ qu'en décubitus dorsal. ${ }^{11}$ Dans une autre étude, les patients préoxygénés en position assise, à un angle se rapprochant le plus possible de $90^{\circ}$, ont également présenté une PASD plus longue (Tableau 3). ${ }^{10}$ Les avantages de la position semi-assise en matière d'oxygénation ne doivent pas faire oublier l'éventualité d'une intubation trachéale plus difficile et une incidence plus élevée d'hypotension à l'induction de l'anesthésie.

Application de pression positive après l'induction

Tout au long de la période périopératoire, la formation d'atélectasies est plus répandue chez les patients obèses que chez les patients minces. La présence d'oxygène à $100 \%$ dans les poumons favorise la formation d'atélectasies en raison du captage de l'oxygène qui quitte ainsi les alvéoles mal ventilés. ${ }^{3,14}$ En présence d'air, l'azote, qui n'est pas capté ou consommé, fournit un support qui garde les alvéoles ouverts. Après l'induction de l'anesthésie, la ventilation en pression positive avec un masque facial augmente la PASD et prévient les atélectasies. ${ }^{14} \mathrm{~L}$ 'application de PEEP augmente également la CRF et prolonge la PASD. Dès lors, une ventilation avec pression positive légère après l'induction, avec ou sans PEEP, pourrait augmenter le temps disponible pour l'intubation trachéale. Cependant, cette technique ne devrait pas être utilisée s'il existe un risque d'inhalation du contenu gastrique.

Ventilation avec pression positive pendant la préoxygénation

Certains chercheurs ont tenté d'appliquer une PEEP $\left(4 \mathrm{cmH}_{2} \mathrm{O}\right)$ et une aide inspiratoire $\left(6 \mathrm{cmH}_{2} \mathrm{O}\right)$ afin d'augmenter l'efficacité de la préoxygénation chez les patients obèses. Sans surprise, la pression positive réduisait

Tableau 3 Techniques de préoxygénation chez le patient obèse

\begin{tabular}{|c|c|c|c|c|c|}
\hline \multirow[t]{2}{*}{ Étude } & \multirow{2}{*}{$\begin{array}{l}\text { Critère } \\
\text { d'évaluation }\end{array}$} & \multicolumn{3}{|c|}{ Technique de préoxygénation } & \multirow[t]{2}{*}{ Commentaires } \\
\hline & & RVC 3 min & 4 ou 8 RP & Autre technique & \\
\hline Goldberg et coll. ${ }^{15}$ & $\mathrm{p}_{\mathrm{a}} \mathrm{O}_{2}(\mathrm{mmHg})$ & 425 & 397 (4 RP) & $*$ & $\mathrm{RVC}=4 \mathrm{RP}$ mais $\mathrm{F}_{\mathrm{EO} 2}$ et PASD pas mesurées \\
\hline Rapaport et coll. ${ }^{16}$ & $\mathrm{~F}_{\mathrm{EO} 2}(\%)$ & $88 \pm 5$ & $84 \pm 4(8 \mathrm{RP})$ & $*$ & $8 \mathrm{RP}=\mathrm{RVC}$ \\
\hline Altermatt et coll..$^{10}$ & PASD (min) & & $2,7 \pm 0,6(8 \mathrm{RP})$ & $\begin{array}{l}3,9 \pm 0,6(\text { position } \\
\left.\text { semi-assise à } 90^{\circ}\right)\end{array}$ & $\begin{array}{l}\text { Position semi-assise mieux que décubitus } \\
\text { dorsal }\end{array}$ \\
\hline Dixon et coll. ${ }^{11}$ & PASD (min) & $2,9 \pm 1,2$ & $*$ & $\begin{array}{l}3,4 \pm 0,9(\text { position } \\
\left.\text { semi-assise à } 25^{\circ}\right)\end{array}$ & $\begin{array}{l}\text { Position semi-assise mieux que décubitus } \\
\text { dorsal }\end{array}$ \\
\hline Delay et coll. ${ }^{12}$ & $\begin{array}{l}\mathrm{F}_{\mathrm{EO} 2}(\%) \\
\mathrm{PASD}(\mathrm{min})\end{array}$ & $\begin{array}{l}94 \pm 2 \\
1,6 \pm 0,6\end{array}$ & * & $\begin{array}{l}97 \pm 1(\mathrm{VPP}) \\
1,7 \pm 0,6(\mathrm{VPP})\end{array}$ & $\begin{array}{l}\text { VPP mieux que RVC pour la } \mathrm{F}_{\mathrm{EO} 2} \text { mais pas } \\
\text { pour la PASD }\end{array}$ \\
\hline
\end{tabular}

RVC $3 \mathrm{~min}=$ respiration à volume courant pendant $3 \mathrm{~min}$;

$4 \mathrm{RP} 30 \mathrm{sec}=$ quatre respirations profondes en $30 \mathrm{sec}$;

$8 \mathrm{RP} 60 \mathrm{sec}=$ huit respirations profondes en $60 \mathrm{sec}$;

$\mathrm{p}_{\mathrm{a}} \mathrm{O}_{2}=$ pression partielle de l'oxygène dans le sang artériel;

PASD = période d'apnée sans désaturation;

$\mathrm{F}_{\mathrm{EO} 2}=$ fraction d'oxygène expiré;

$\mathrm{VPP}=$ ventilation en pression positive;

$*$ non réalisé 
Tableau 4 Techniques de préoxygénation chez la femme enceinte

\begin{tabular}{|c|c|c|c|c|c|}
\hline \multirow[t]{2}{*}{ Étude } & \multirow[t]{2}{*}{ Critère d'évaluation } & \multicolumn{3}{|c|}{ Technique de préoxygénation } & \multirow[t]{2}{*}{ Commentaires } \\
\hline & & RVC 3 min & 4 ou $8 \mathrm{RP}$ & Autres techniques & \\
\hline 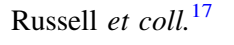 & $\mathrm{F}_{\mathrm{EO} 2}(\%)$ & Non spécifié & $79 \pm 4(4 \mathrm{RP})$ & $*$ & RVC 3 min mieux que $4 \mathrm{RP}$ \\
\hline 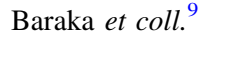 & PASD (min) & $2,9 \pm 0,1$ & $*$ & $\begin{array}{l}2,6 \pm 0,1 \text { (position } \\
\text { semi-assise) }\end{array}$ & $\begin{array}{l}\text { La position semi-assise } \\
\text { n'a pas d'avantages }\end{array}$ \\
\hline Bernard et coll. ${ }^{18}$ & PASD (min) & $2,3 \pm 1,3$ & $2,4 \pm 1,0(4 \mathrm{RP})$ & $*$ & $\mathrm{RVC} 3 \min =4 \mathrm{RP}$ \\
\hline Chiron et coll. ${ }^{19}$ & $\mathrm{~F}_{\mathrm{EO} 2}(\%)$ & $89 \pm 5$ & $\begin{array}{l}83 \pm 6(4 \mathrm{RP}) \\
90 \pm 6(8 \mathrm{RP})\end{array}$ & $*$ & $\begin{array}{l}\mathrm{RVC} 3 \text { min et } 8 \mathrm{RP} \\
\quad \text { mieux que RVC } 3 \text { min }\end{array}$ \\
\hline
\end{tabular}

RVC 3 min = respiration à volume courant pendant 3 min;

$4 \mathrm{RP} 30 \mathrm{sec}=$ quatre respirations profondes en $30 \mathrm{sec}$;

$8 \mathrm{RP} 60 \mathrm{sec}=$ huit respirations profondes en $60 \mathrm{sec}$;

$\mathrm{F}_{\mathrm{EO} 2}=$ fraction d'oxygène expiré;

PASD = période d'apnée sans désaturation;

$*=$ non réalisé

le temps nécessaire à atteindre une $\mathrm{F}_{\mathrm{EO} 2}>95 \%$, sans toutefois allonger la PASD (154 vs $161 \mathrm{sec}) .{ }^{12}$ On a trouvé un plus grand volume d'air dans l'estomac des patients ayant reçu une pression positive, mais cette quantité n'a pas été considérée comme significative d'un point de vue clinique (moyenne de $18 \mathrm{~mL}$ vs $4 \mathrm{~mL}$ dans le groupe témoin). ${ }^{12}$ Les données probantes à notre disposition à l'heure actuelle sont trop limitées pour recommander le recours à cette technique dans la pratique quotidienne.

\section{La préoxygénation chez la femme enceinte}

Physiologie

Au fur et à mesure que l'abdomen grossit au fil de la grossesse, le diaphragme est poussé vers le haut et la CRF diminue. De plus, la consommation d'oxygène et la ventilation minute augmentent toutes deux de façon marquée, alors que la $\mathrm{pCO}_{2}$ artérielle diminue. Par conséquent, la $\mathrm{F}_{\mathrm{EO} 2}$ augmente plus rapidement pendant la préoxygénation chez la femme enceinte que chez une femme du même âge non enceinte. Par exemple, il a fallu en moyenne $80 \mathrm{sec}$ pour atteindre une $\mathrm{F}_{\mathrm{EN} 2}$ de $2 \%$ en fin de grossesse, comparativement à $104 \mathrm{sec}$ en début de grossesse et $130 \mathrm{sec}$ chez les femmes non enceintes. ${ }^{17}$ Cependant, la PASD est plus courte chez la femme enceinte que chez la femme non enceinte (Tableau 1). ${ }^{17}$

\section{Technique de préoxygénation}

Avec la technique de RVC, l'augmentation de la $\mathrm{F}_{\mathrm{EO} 2}$ est plus rapide chez les femmes devant subir une césarienne (en raison de la $\mathrm{CRF}$ réduite et de la ventilation minute plus élevée) que chez des femmes non enceintes. ${ }^{17}$ Toutefois, comme c'est le cas chez l'obèse, l'efficacité de la technique de 4 RP 30 sec pourrait être limitée en raison d'une diminution de la capacité vitale. Dans une étude, la PASD était la même avec les techniques de RVC 3 min et de 4 RP $30 \mathrm{sec}^{18}$ Cependant, deux autres études ont montré une réduction de la $\mathrm{F}_{\mathrm{EO} 2}$ après $4 \mathrm{RP} 30 \mathrm{sec}$ (Tableau 4). ${ }^{17,19}$ Dès lors, si une technique rapide est utilisée, celle de 8 RP 60 sec est recommandée. ${ }^{19}$ Il faut cependant noter que la PASD pourrait être aussi brève que $1 \mathrm{~min}$ chez certaines patientes, quelle que soit la méthode de préoxygénation utilisée. À l'inverse des patients obèses, la position semi-assise n'a pas conféré d'avantages chez la femme enceinte. ${ }^{9}$ Cela est probablement dû au fait que la distribution du tissu adipeux n'est pas la même chez les parturientes et les patients obèses morbides, et que l'utérus gravide diminue sensiblement l'excursion diaphragmatique, quelle que soit la position.

\section{La préoxygénation chez le patient âgé}

Physiologie

Chez l'adulte sain, la capacité pulmonaire totale ne change pas beaucoup en vieillissant, mais le volume de fermeture augmente suffisamment pour provoquer un shunt intrapulmonaire plus grand. Étant donné que la ventilation minute est diminuée, le temps nécessaire pour obtenir la $\mathrm{F}_{\mathrm{EO} 2}$ souhaitée pourrait se prolonger au-delà des 3 min de RVC habituelles. Toutefois, à moins qu'un shunt important soit présent en raison d'une maladie, une préoxygénation adaptée pourrait permettre aux patients âgés, qui démontrent une consommation d'oxygène plus basse, de soutenir une période d'apnée légèrement plus longue que les patients plus jeunes (Tableau 1). 
Techniques de préoxygénation

La méthode de RVC est en général plus efficace que les techniques de RP, mais il est possible que le temps requis pour obtenir les valeurs souhaitées soit prolongé. La technique de 4 RP $30 \mathrm{sec}$ n'est pas aussi efficace que la RVC chez le patient âgé (Tableau 5), ${ }^{20,21}$ et la technique de 8 RP $60 \mathrm{sec}$ n'a pas encore été étudiée dans cette population. Dans la pratique, la coopération peut s'avérer plus ardue ; les fuites peuvent être plus fréquentes en raison de la perte de tonus des muscles de la mâchoire et des joues et de l'absence de dents, et le shunt peut être plus grand que chez les patients plus jeunes en raison d'une perte de tissu pulmonaire liée au tabagisme ou à l'âge.

\section{Causes d'une préoxygénation inadéquate}

Facteurs techniques

Bien que la $\mathrm{F}_{\mathrm{EO} 2}$ puisse, en théorie, atteindre $95 \%$, une $\mathrm{F}_{\mathrm{EO} 2}$ $>90 \%$ est, en pratique, généralement considérée comme satisfaisante. Si l'on ne parvient pas à un tel niveau, trois causes sont possibles : 1 ) un débit d'oxygène faible ; 2) une période de préoxygénation insuffisante ; et/ou 3) des fuites. Alors que les deux premiers facteurs sont faciles à corriger, les fuites sont fréquentes et il peut être plus difficile de les diagnostiquer et d'y remédier. Des fuites ont été rapportées chez $11,5 \%$ des patients présentant une anatomie faciale et une dentition normales. ${ }^{22}$ Les fuites peuvent être plus fréquentes chez les patients édentés ou barbus ou chez les patients présentant des anomalies faciales, des brûlures, ou une sonde nasogastrique. ${ }^{4} \mathrm{Il}$ faut soupçonner une fuite si le ballon du circuit ne demeure pas gonflé, si l'on peut détecter le gaz s'échappant autour du masque facial, ou si la $\mathrm{F}_{\mathrm{EO} 2}$ atteint un plateau dans les $50-80 \%$ (Fig. 2). ${ }^{4}$

Facteurs humains

La préoxygénation peut s'avérer difficile voire impossible si le patient est peu coopératif, claustrophobe, ou excessivement anxieux ou si l'anesthésie doit être induite très rapidement. Dans ces cas-là, les techniques rapides peuvent être utiles. Elles nécessitent moins de temps, et il est possible qu'un patient coopère davantage s'il lui est demandé d'accomplir une tâche brève qui nécessite son attention.

\section{Interface patient - circuit}

L'interface entre le circuit utilisé pour la préoxygénation et le patient est en général un masque facial, lequel peut être refusé par certains patients et est enclin aux fuites. Des alternatives au masque traditionnel ont été proposées pour améliorer la préoxygénation, éviter les fuites et prolonger la PASD.

\section{Débit d'oxygène élevé}

Si l'oxygène est fourni à un débit plus élevé que le débit inspiratoire maximal, alors les fuites ne sont plus un problème. Les débits inspiratoires peuvent atteindre 30 $\mathrm{L} \cdot \mathrm{min}^{-1}$ pendant une respiration calme. Une préoxygénation efficace peut être effectuée avec de l'oxygène à un débit de $48 \mathrm{~L} \cdot \mathrm{min}^{-1}$ avec un masque peu étanche $;^{23}$ mais les machines anesthésiques ne fournissent en général pas des débits aussi élevés. Le recours au mode de purge d'oxygène n'est pas recommandé en raison de la pression élevée qu'il génère.

Le circuit directement à la bouche

Dans les situations où les fuites sont probables (par ex. barbe, sonde nasogastrique) ou lorsque le patient refuse le masque facial, il est possible de demander au patient d'appliquer sa bouche directement autour du connecteur du circuit. Durant une RVC, il est souvent nécessaire d'avoir recours à un pince-nez. Toutefois, avec les techniques rapides, la respiration nasale est rare et un pince-nez n'est en général pas nécessaire. ${ }^{24}$

\section{Système NasOral ${ }^{\circledR}$}

Conçu spécifiquement pour la préoxygénation, le système NasOral ${ }^{\circledR}$ (Logo Med, GmbH, Windhagen, Allemagne)

Tableau 5 Techniques de préoxygénation chez le patient âgé

\begin{tabular}{lllll}
\hline Étude & Critère d'évaluation & RVC 3 min & 4 RP 30 sec & Commentaires \\
\hline Valentine et coll. ${ }^{20}$ & PASD (min) & $6,8 \pm 1,3$ & $3,9 \pm 1,5$ & RVC mieux que 4 RP \\
McCarthy et coll. $^{21}$ & PASD (min) & $5,4 \pm 1,4$ & $3,4 \pm 1,4$ & RVC mieux que 4 RP \\
\hline
\end{tabular}

$\mathrm{RVC} 3 \mathrm{~min}=$ respiration à volume courant pendant $3 \mathrm{~min}$;

$4 \mathrm{RP} 30 \mathrm{sec}=$ quatre respirations profondes en $30 \mathrm{sec}$;

PASD $=$ période d'apnée sans désaturation 
est un dispositif qui permet l'inspiration par le nez et l'expiration par la bouche grâce à l'utilisation de valves unidirectionnelles, qui empêchent la réinhalation. La $\mathrm{F}_{\mathrm{EO} 2}$ obtenue avec ce système est comparable à celle obtenue avec un masque facial. Cependant, le clinicien doit changer de système une fois le patient inconscient. De plus, ce dispositif ne peut pas être utilisé chez les patients qui ne peuvent pas respirer par le nez ou par la bouche. ${ }^{25}$ Ces inconvénients, ainsi que les coûts supplémentaires pour l'acquisition du système NasOral ${ }^{\circledR}$, ont freiné son introduction dans la pratique clinique.

\section{Cathéter nasopharyngé}

L'oxygène quitte les alvéoles pour être consommé pendant l'apnée. Il est remplacé par un volume beaucoup moins important de $\mathrm{CO}_{2}$ en raison de la capacité tampon élevée du sang pour le $\mathrm{CO}_{2}$. Ainsi, si les voies aériennes sont dégagées, le gaz est amené des voies aériennes supérieures jusqu'aux alvéoles et ce, même en l'absence de mouvements respiratoires. Si ce gaz est composé principalement d'oxygène, il fournit une réserve supplémentaire à l'organisme et prolonge la PASD. C'est pour cette raison que les donneurs d'organes évitent l'hypoxie pendant un test d'apnée si de l'oxygène est fourni à la sonde trachéale. Le même principe s'applique lorsqu'un cathéter connecté à une source d'oxygène fournissant $2-5 \mathrm{~L} \cdot \mathrm{min}^{-1}$ est placé dans le nez ou la bouche après l'induction de l'anesthésie. Dans une étude, tous les patients chez qui on avait inséré un cathéter nasopharyngé avec de l'oxygène $\left(5 \mathrm{~L} \cdot \mathrm{min}^{-1}\right)$ avaient une $\mathrm{SpO}_{2}=100 \%$ après 6 min d'apnée, alors que la $\mathrm{SpO}_{2}$ a diminué à $95 \%$ dans un temps moyen de 3,65 min chez ceux à qui on ne donnait pas d'oxygène. ${ }^{26}$ Dans une autre étude, l'insufflation de $3 \mathrm{~L} \cdot \mathrm{min}^{-1}$ a permis de prolonger la période d'apnée de $7 \mathrm{~min}$ à plus de 10 min. ${ }^{27}$ Cette technique a été utilisée avec succès chez des patients obèses, la PASD passant d'une moyenne de 2,4 min sans un tel dispositif à 4 min chez 16 des 17 patients lorsque de l'oxygène était fourni par un cathéter nasopharyngé à un débit de $5 \mathrm{~L} \cdot \mathrm{min}^{-1} \cdot{ }^{28} \mathrm{~L}$ 'un des inconvénients de cette technique est qu'elle nécessite une manipulation supplémentaire après l'induction de l'anesthésie.

\section{Effets secondaires de la préoxygénation}

\section{Effets hémodynamiques}

L'oxygène a des effets cardiovasculaires limités mais mesurables. Il augmente la résistance vasculaire systémique et réduit le débit et la fréquence cardiaques. ${ }^{29} \mathrm{Ces}$ changements sont mineurs.
Effets sur les gaz sanguins

Hormis une augmentation de la $\mathrm{p}_{\mathrm{a}} \mathrm{O}_{2}$, la préoxygénation peut réduire la $\mathrm{pCO}_{2}$ si des techniques de respirations profondes (rapides) sont utilisées. ${ }^{4,7}$ Une réduction de la $\mathrm{pCO}_{2}$ artérielle pourrait augmenter la dose d'agents d'induction nécessaire à l'anesthésie, probablement en raison d'une diminution concomitante du débit sanguin cérébral à cause de l'hypocarbie. ${ }^{30}$ Pendant l'apnée, la $\mathrm{pCO}_{2}$ augmente de 3-6 $\mathrm{mmHg} \cdot \mathrm{min}^{-1}$.

\section{Atélectasie}

Des zones atélectasiques surviennent plus souvent après avoir inspiré de l'oxygène à $100 \%$ qu'après avoir inspiré de l'oxygène à 60 ou $80 \%{ }^{3}$ Ceci est particulièrement vrai chez les patients obèses. ${ }^{14}$ Toutefois, plusieurs manœuvres comme l'utilisation de PEEP et les méthodes de recrutement alvéolaire peuvent être utilisées pendant l'anesthésie et la ventilation mécanique pour limiter l'étendue de ce problème. $^{14}$ De plus, l'atélectasie est plus courante en période postopératoire, et elle dépend principalement de l'hypoventilation postopératoire et de la concentration d'oxygène inspirée à la fin de l'anesthésie. Par conséquent, il n'est pas justifié d'éviter la préoxygénation seulement afin d'éviter l'atélectasie.

\section{Conclusion}

La préoxygénation est une première étape essentielle à la prise en charge des voies aériennes car elle réduit le risque d'hypoxie après l'induction de l'anesthésie. La période d'apnée que peut tolérer un patient sans présenter de désaturation dépend non seulement de la méthode de préoxygénation (lente ou rapide), mais aussi de sa CRF et de sa consommation d'oxygène. Les techniques de RVC 3 min ou de 8 RP $60 \mathrm{sec}$ devraient être utilisées, et la technique de 4 RP $30 \mathrm{sec}$ devrait être abandonnée. Les patients obèses et les femmes enceintes courent un risque plus élevé d'hypoxie et nécessitent une préoxygénation minutieuse.

\section{Cas clinique}

Un patient âgé de 65 ans pesant $110 \mathrm{~kg}$, mesurant $170 \mathrm{~cm}$ et avec un indice de masse corporelle de $38 \mathrm{~kg} \cdot \mathrm{m}^{-2}$ se présente pour subir une laparotomie d'urgence pour occlusion intestinale. Les signes vitaux du patient sont : pression artérielle $140 / 85 \mathrm{mmHg}$, fréquence cardiaque $110 \cdot \mathrm{min}^{-1}$, fréquence respiratoire $24 \cdot \mathrm{min}^{-1}$, température $38,8^{\circ} \mathrm{C}$, et saturation en oxygène à $92 \%$ à l'air. Une 
tomodensitométrie assistée par ordinateur de l'abdomen indique une ascite d'origine inconnue. Une radiographie pulmonaire indique des atélectasies aux deux bases. Il n'a pas d'antécédents médicaux pertinents. Une sonde nasogastrique a été insérée. Un examen des voies aériennes révèle l'absence d'anomalie et on prévoit une intubation trachéale aisée. Vous décidez de réaliser une induction en séquence rapide.

\section{Directives pour compléter le module DPC}

1) Lisez les références indiquées en gras.

2) Consultez le site Internet du Journal canadien d'anesthésie (http://www.springer.com/medicine/anesthesiology/ journal/12630), cliquez sur « DPC en ligne », et choisissez le module actuel (Optimiser la préoxygénation chez l'adulte).

3) Répondez aux questions à choix de réponses concernant le cas.

4) Une fois que vous avez saisi toutes vos réponses, vous aurez accès aux explications d'experts pour tous les choix possibles.

5) Les participants peuvent réclamer un maximum de quatre heures de DPC pour un total de huit crédits sous la Sect. 3 du programme de DPC du Collège royal des médecins et chirurgiens du Canada.

\section{Conflicts of interest None declared.}

\section{References}

(In order to complete the learning section of this CPD module and claim CPD credits, please read the three bolded references below prior to answering the MCQ questions).

1. Benumof JL. Preoxygenation: best method for both efficacy and efficiency. Anesthesiology 1999; 91: 603-5.

2. Bourgain $J L$. Préoxygénation et manoeuvres de contrôle de la perméabilité des voies aériennes. Ann Fr Anesth Reanim 2003; 22(Suppl 1): 41s-52s.

3. Edmark L, Kostova-Aherdan $K$, Enlund M, Hedenstierna G. Optimal oxygen concentration during induction of general anesthesia. Anesthesiology 2003; 98: 28-33.

4. Gagnon C, Fortier LP, Donati $F$. When a leak is unavoidable, preoxygenation is equally ineffective with vital capacity or tidal volume breathing. Can J Anesth 2006; 53: 86-91.

5. Gambee AM, Hertzka RE, Fisher DM. Preoxygenation techniques: comparison of three minutes and four breaths. Anesth Analg 1987; 66: 468-70.

6. Baraka AS, Taha SK, Aouad MT, El-Khatib MF, Kawkabani NI. Preoxygenation: comparison of maximal breathing and tidal volume breathing techniques. Anesthesiology 1999; 91: 612-6.
7. Nimmagadda U, Chiravuri SD, Salem MR, et al. Preoxygenation with tidal volume and deep breathing techniques: the impact of duration of breathing and fresh gas flow. Anesth Analg 2001; 92: 1337-41.

8. Pandit JJ, Duncan T, Robbins PA. Total oxygen uptake with two maximal breathing techniques and the tidal volume breathing technique: a physiologic study of preoxygenation. Anesthesiology 2003 ; 99: 841-6.

9. Baraka AS, Hanna MT, Jabbour SI, et al. Preoxygenation of pregnant and nonpregnant women in the head-up versus supine position. Anesth Analg 1992; 75: 757-9.

10. Altermatt FR, Munoz HR, Delfino AE, Cortínez LI. Pre-oxygenation in the obese patient: effects of position on tolerance to apnoea. Br J Anaesth 2005; 95: 706-9.

11. Dixon BJ, Dixon JB, Carden JR, et al. Preoxygenation is more effective in the 25 degrees head-up position than in the supine position in severely obese patients: a randomized controlled study. Anesthesiology 2005; 102: 1110-5.

12. Delay JM, Sebbane M, Jung B, et al. The effectiveness of noninvasive positive pressure ventilation to enhance preoxygenation in morbidly obese patients: a randomized controlled study. Anesth Analg 2008; 107: 1707-13.

13. Jense HG, Dubin SA, Silverstein PI, O'Leary-Escolas U. Effect of obesity on safe duration of apnea in anesthetized humans. Anesth Analg 1991; 72: 89-93.

14. Coussa M, Proietti S, Schnyder P, et al. Prevention of atelectasis formation during the induction of general anesthesia in morbidly obese patients. Anesth Analg 2004; 98: 1491-5.

15. Goldberg ME, Norris MC, Larijani GE, Marr AT, Seltzer JL. Preoxygenation in the morbidly obese: a comparison of two techniques. Anesth Analg 1989; 68: 520-2.

16. Rapaport S, Joannes-Boyau O, Bazin R, Janvier G. Comparaison de la technique de préoxygénation à huit capacités vitales et à volume courant chez les patientes ayant une obésité morbide. Ann Fr Anesth Reanim 2004; 23: 1155-9.

17. Russell GN, Smith CL, Snowdon SL, Bryson TH. Pre-oxygenation and the parturient patient. Anaesthesia 1987; 42: 346-51.

18. Bernard F, Louvard V, Cressy ML, Tanguy M, Malledant $Y$. Préoxygénation avant induction pour césarienne. Ann Fr Anesth Reanim 1994; 13: 2-5.

19. Chiron B, Laffon $M$, Ferrandiere $M$, Pittet JF, Marret $H$, Mercier $C$. Standard preoxygenation technique versus two rapid techniques in pregnant patients. Int J Obstet Anesth 2004; 13: $11-4$.

20. Valentine SJ, Marjot R, Monk CR. Preoxygenation in the elderly: a comparison of the four-maximal-breath and three-minute techniques. Anesth Analg 1990; 71: 516-9.

21. McCarthy G, Elliott P, Mirakhur RK, McLoughlin C. A comparison of different pre-oxygenation techniques in the elderly. Anaesthesia 1991; 46: 824-7.

22. Machlin HA, Myles PS, Berry CB, Butler PJ, Story DA, Heath BJ. End-tidal oxygen measurement compared with patient factor assessment for determining preoxygenation time. Anaesth Intens Care 1993; 21: 409-13.

23. Ooi R, Pattison J, Joshi P, Chung R, Soni N. Pre-oxygenation: the Hudson mask as an alternative technique. Anaesthesia 1992; 47: 974-6.

24. Winship S, Skinner A. Vital capacity and tidal volume preoxygenation with a mouthpiece. Br J Anaesth 1998; 81: 787-9.

25. Hirsch J, Fuhrer I, Kuhly P, Schaffartzik W. Preoxygenation: a comparison of three different breathing systems. Br J Anaesth 2001; 87: 928-31.

26. Taha SK, Siddik-Sayyid SM, El-Khatib MF, Dagher CM, Hakki $M A$, Baraka AS. Nasopharyngeal oxygen insufflation following pre-oxygenation using the four deep breath technique. Anaesthesia 2006; 61: 427-30. 
27. Teller LE, Alexander CM, Frumin MJ, Gross JB. Pharyngeal insufflation of oxygen prevents arterial desaturation during apnea. Anesthesiology 1988; 69: 980-2.

28. Baraka AS, Taha SK, Siddik-Sayyid SM, et al. Supplementation of pre-oxygenation in morbidly obese patients using nasopharyngeal oxygen insufflation. Anaesthesia 2007; 62: 769-73.
29. Anderson KJ, Harten JM, Booth MG, Kinsella J. The cardiovascular effects of inspired oxygen fraction in anaesthetized patients. Eur J Anaesthesiol 2005; 22: 420-5.

30. Tripathi M, Raza M, McCoy E, Pandey M, Pandey CM. Effect of preoxygenation practices on bispectral index and the propofol induction. Br J Anaesth 2008; 101: 576-8. 